\title{
A Method for Gauging Landscape Change as a Prelude to Urban Watershed Regeneration: The Case of the Carioca River, Rio de Janeiro
}

\author{
Mônica Bahia Schlee ${ }^{1, *}$, Kenneth R. Tamminga ${ }^{2}$ and Vera Regina Tangari ${ }^{3}$ \\ 1 City of Rio de Janeiro, Macro Urban Planning Department/Municipal Secretary of Urban \\ Planning-CMP/SMU/PCRJ, Rua Santa Cristina 121, Santa Teresa, Rio de Janeiro, \\ Cep. 20241-250, Brazil
}

2 Department of Landscape Architecture, 121 Stuckeman Family Building, Penn State University, University Park, PA 16802, USA; E-Mail: krt1@psu.edu

3 School of Architecture and Urbanism, Federal University of Rio de Janeiro-FAU/UFRJ, R. Jornalista Orlando Dantas 62 apt. 403 , Rio de Janeiro, Cep. 22231-010, Brazil;

E-Mail: vtangari@uol.com.br

* Author to whom correspondence should be addressed; E-Mail: monbasch@gmail.com; Tel.: +55-021-92047249 or +1-206-430-3227.

Received: 25 June 2012; in revised form: 13 August 2012 / Accepted: 13 August 2012 / Published: 31 August 2012

\begin{abstract}
Natural systems undergo processes, flows, and rhythms that differ from those of urban sociocultural systems. While the former takes place over eras or many generations, the latter may occur within years or even months. Natural systems change includes no principle of intentional progress or enhancement of complexity. In contrast, sociocultural systems change occurs through inherited characteristics, learning, and cultural transmission [1]. Both are dynamic, heterogeneous, and vulnerable to regime shifts, and are inextricably linked. The interrelations among natural and anthropogenic factors affecting sustainability vary spatially and temporally. This paper focuses on landscape changes along the Carioca River valley in Rio de Janeiro, located in the Brazilian Neotropical Southeastern Region, and its implications for local urban sustainability. The study incorporates a transdisciplinary approach that integrates landscape ecology and urban morphology methodologies to gauge landscape change and assess social-ecological systems dynamics. The methodology includes a variety of landscape change assessments; including on-site landscape ecological, landscape morphology, biological and urbanistic surveys, to gauge urban watershed quality. It presents an adapted inventory for assessment
\end{abstract}


of urban tropical rivers, Neotropical Urban Stream Visual Assessment Protocol (NUSVAP), and correlates the level of stream and rainforest integrity to local urban environmental patterns and processes. How can urban regional land managers, planners and communities work together to promote shifts toward more desirable configurations and processes? An understanding of the transient behavior of social-ecological systems and how they respond to change and disturbance is fundamental to building appropriate management strategies and fostering resilience, regenerative capacity, and sustainable development in urban watersheds. The sociocultural patterns, processes and dynamics of Rio's hillsides suggest that increasing the multifunctionality, flexibility, adaptability and connectivity of open spaces may influence carrying, adaptive and regenerative capacities of urban landscape systems.

Keywords: landscape morphology; landscape dynamics; edge effect; regenerative riparian urbanism; social-ecological systems; resilience

\section{Introduction}

Conflicts between urban growth, landscape protection and sustainable development have been the subject of discussion worldwide since the late 1980s. In Rio de Janeiro, this issue deserves particular attention. Real estate and land use pressures on urban rainforest and water bodies are incessant, especially within the Tijuca Massif where the 39 square kilometer Tijuca National Park (TNP)—one of the largest protected rainforest urban parks in the world-is located.

The Carioca River is located within the metropolitan Rio de Janeiro ("Rio") limits, in the Neotropical Southeastern Region of Brazil (see Figure 1). Processes of landscape change along the river reflect transformations that occurred throughout the Tijuca Massif, as well as larger landscape evolution of the city of Rio de Janeiro, all of which are linked to Brazilian and international conjunctures at the time the events took place. As with other valleys throughout the city, the Carioca River ("the Carioca") corridor functioned as a vector of urban expansion, allowing an "against the flow" movement towards the slopes of the Tijuca Massif. The expansion process was gradual and occurred in several stages, each contributing to the Carioca's profound transformation. The Carioca River, in its riparian context, was chosen as a focus of study because it is a dynamic local agent of landscape change that remarkably reflects the tension between nature and Rio de Janeiro's urbanization over almost five centuries. 
Figure 1. Location of the Carioca River Watershed [2].
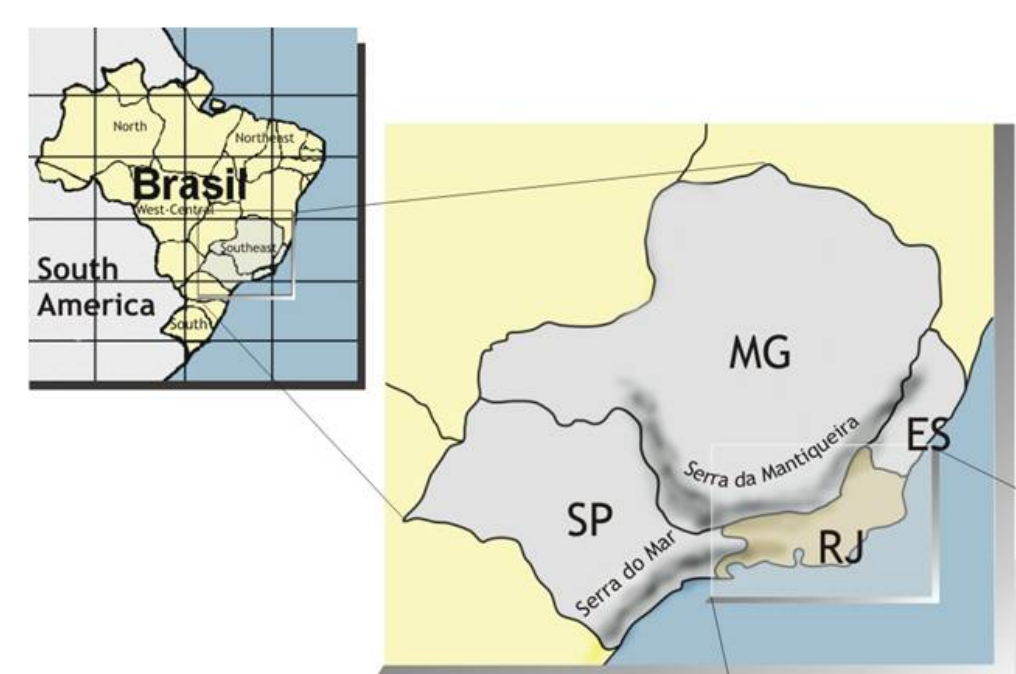

Southeast Region

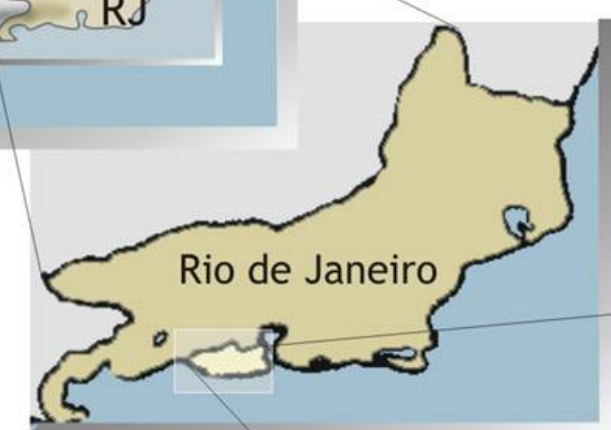

State of Rio de Janeiro

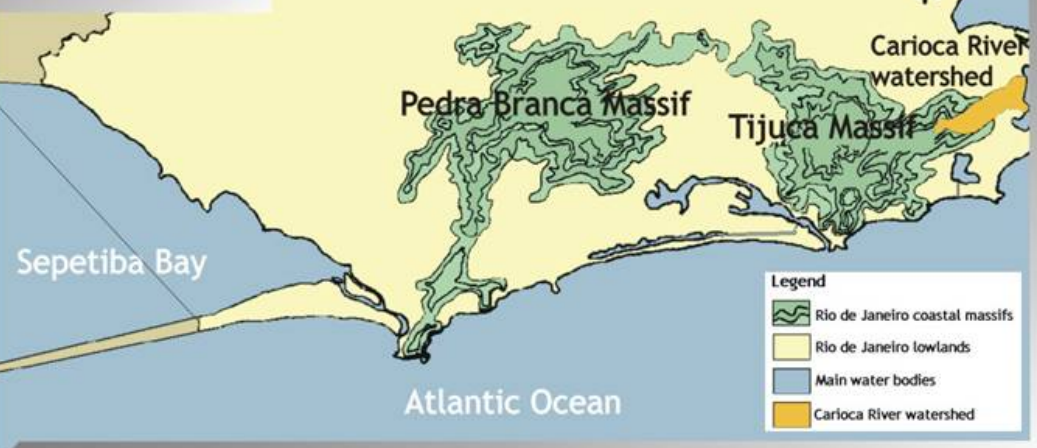

Rio de Janeiro City 
This article reviews and discusses the methods applied over 10 years of research on landscape change in the Carioca River watershed from the perspective of landscape sustainability. The work is an extension of thesis research conducted through Pennsylvania State University in 2002 [2], and the doctoral dissertation defended at the Federal University of Rio de Janeiro in 2011 [3]. The analyses were made from a series of on-site assessments and GIS mapping, grounded in a transdisciplinary approach that integrates historical, biological, urban morphological and landscape ecological perspectives and methods. It presents an adapted inventory to urban tropical rivers, Neotropical Urban Stream Visual Assessment Protocol (NUSVAP), a tool designed to assist participatory analysis of the effects of landscape change upon urban watershed environmental conditions and sustainability caused by urbanization that prevails in the coastal cities of Brazil.

Much has been written about sustainability. Yet there are huge challenges to putting it into practice. Its multiple contents allows for ambiguity and competing interpretations. Most broadly, sustainability may be defined as the set of attitudes and responsibilities of humanity towards its and its habitat preservation in the future. However, since the term was embraced by the Brundtland Commission [4], critics have challenged its emphasis on economic growth, technological progress, and energy saving as a means of promoting capitalist hegemony [5-7]. As argued by Acselrad, Folke, Holdren and Ehrlich [6-9], the sustainability ideal would seek moderate economic development while pursuing environmental health and integrity and social justice, for the common good of present and future generations. In any case, tensions between the logic of economic growth and environmental and social equality are still imprinted in government policies and practices worldwide.

Landscape planning and management for sustainability encompasses physical, social, public policy and economic dimensions [10]. Not surprisingly, current discourses on landscape sustainability are still fragmented and disperse. This paper focuses on the physical dimension of urban landscape sustainability and stresses that explaining the real world, as argued by Johnson and Hill [11], is a key strategy for achieving sustainability. Environmental damage is frequently not reversible. However, abrupt changes may be estimated if the dynamic effects of changes are considered (e.g., thresholds, buffering capacity, and loss of resilience), and if appropriate measures of landscape change are taken [5]. In other words, gauging and monitoring phases are key steps to understanding environmental and socio-cultural conditions and resilience thresholds. These awarenesses are fundamental for planning and management efforts that wish to promote a progressive and equitable sustainability agenda.

The methodological framework applied and developed in this research matches and builds on current methodological approaches for sustainable landscape planning, which, as showed by Leitao and Ahern [10], evolved from quantitative techniques developed in the 1950s and qualitative analyses based on overlay approaches [12] and social-economic investigations developed during the 1960s and 1970s, both of which advanced progressively after the application of geographical information systems analyses since the 1980s. Structure, function, quality, suitability and impact analyses, and the identification of alternative/future scenarios were added during the 1980s and 1990s [13-21]. Ndubisi [22] traces concurrent and similar (if somewhat more subversive) developments in ecological planning. Advances during the 1990s to the present included the analysis of processes, conflicts, opportunities and threats using elaborate landscape metrics, and the acknowledgement of the fundamental role of ecological and socio-cultural interconnections as a basis of human health and 
wellness [10,14-17,23-26]. Collectively, this body of theory and methods leads to fundamental conceptual recommendations for planning as well as for managing towards sustainability. These include:

- Enhance and strengthen environmental awareness among urban decision-makers and inhabitants;

- Acknowledge human and environmental connectivity;

- Strive for cultural and social cohesiveness towards sustainability;

- Focus on the source, not on the resource;

- Assure public participation in all the planning and management phases.

More recently, the interplay between landscape resilience and landscape sustainability has been stressed by different authors [5,7,8,27-30 among others]. Resilience focuses on the carrying and adaptive capacity of a system to absorb and adapt in the face of change, regime shift and disturbance, and the ability to recover or reorganize in order to retain structure, function and identity. The landscape resilience approach emphasizes non-linear dynamics and builds on feedbacks of interlinked social-ecological systems [5,7,29,30].

Planning for sustainability, as argued by Forman [14] requires recognizing the transient behavior of landscape systems, as well as the interplay of human activities and ecosystems resilience, as interdependent factors. As will be demonstrated in this paper, landscape gauging and monitoring should be done at different levels and scales, using metrics in comparative terms to provide solid understanding about pattern-process relationships and levels of disturbance and resilience.

Morphology, function, scale and time are fundamental components of landscape systems. Urban landscape morphology focuses on the tangible results of natural and social forces in continuous, dynamic and pervasive interrelationships, continuously transformed through time. Landscapes are process-dependent systems. A cross-scale landscape approach can help to structure urban landscape planning and contribute to advancing its theory and practice towards the goal of sustainability. Understanding social-ecological system dynamics and its implications for sustainability requires shifting from aspirations to control change to managing adaptive capacity [5,8].

We argue that the accomplishment of the spatial urban dimension of sustainability requires the understanding of processes and relations between ecosystems, urban social systems and urban land uses across different scales through time. Recognizing the importance of landscape configuration, landscape change and cross-scale interplay, as well as ecological and cultural knowledge, are fundamental issues in planning for sustainability.

Pattern-process relationships, as well as functional socio-cultural relationships, may provide insights to assist and select adequate planning strategies. The cross-reference of biophysical, ecological, landscape and socio-cultural inquiries during 10 years of research in the Carioca River watershed reveals the effects of current patterns and processes of on-going urban development and indicates interdependences and interactions between the natural and the built environments. The integrated methods applied and developed in this research coalesce into a robust methodology for sustainable landscape planning that may be employed to help gauge resilience and carrying and adaptive capacity. 


\section{Methods}

Two bodies of theory underpin our research: landscape ecology and urban morphology. Each alone is insufficient to inform the complex challenge of urban watershed assessment and regeneration actions. Taken in tandem, there remains the strategic problem of how best to achieve a selective but robust hybrid of the two in order to address urban and peri-urban environments. Landscape ecology studies the composition, structure, processes and functions of nature and the relationships among its diverse features, focusing mainly on natural ecosystems [13,15,31]. Urban morphology investigates the configuration, character, structure, functions and processes of urban settings [32-34]. Landscape ecology evolved as an interdisciplinary field with the focus on landscape pattern-process relationships. More recently, landscape ecology acknowledges that natural and cultural systems are interlinked and inherently variable and prone to change $[5,7,15,25,28-30,35]$. Yet despite advances in the two fields, their theoretical-methodological approaches still largely focus on compartmentalized themes in a way that fails to grasp the multitude of spatial and temporal relationships between the natural environment and urban form and socio-political dynamics. The resulting gaps point to the need for a synthesis that unifies these fields around an integrated body of knowledge in order to address, investigate and evaluate social-ecological systems in the city.

The urban hillside landscape of Rio de Janeiro and its water bodies are complex socio-ecological systems [27,36]. Resilience issues in mountainous peri-urban areas are also very complex. Hence, the importance of merging the contributions of landscape ecology to the methodological scope of urban morphology. The methodologies applied in this research were chosen with the goal of developing insights into specific socio-ecological systems aspects, behaviors and processes through time. As will be demonstrated below, this required that we clarify the relationships among them, as seen through the lenses of landscape morphology and landscape change features expressed in watershed spaces at several scales. These parameters include watershed, slope and stream conditions; biota and habitat conditions; edge effect; water quality and sanitary infrastructure; land use and land cover; land ownership; land regulation; and parceling and open space conditions. In-depth socio-economic dynamics and political context analyses were beyond the scope of the research and thus are not addressed in this article. 


\subsection{Methods Applied in Research Phase 1 (2000-2002)}

The methodological approach of the initial research phase (2000-2002) along the Carioca River watershed built on several techniques to gauge landscape change and evaluate environmental and landscape conditions:

- historical analyses (research at local archives and GIS mapping, correlating past and current conditions);

- comparison with reference rivers that function as parameters of quality and are located in the same geographic region as the Carioca (Atlantic Rainforest biome);

- identification of main environmental impacts that affect the watershed under study;

- application of two stream visual assessment protocols: the Riparian, Channel and Environmental Inventory [37] and the Stream Visual Assessment Protocol [38];

- biochemical and biological on-site assessments of water quality;

- development of a hybrid protocol more attuned to neotropical urban streams (the Neotropical Urban Stream Visual Assessment Protocol-NUSVAP), using local ecological indicators of water quality and rainforest integrity;

- GIS mapping of landscape ecology, biological and urban parameters at 1:10,000 scale: geomorphology, water quality, land use and vegetation cover evolution (1972, 1984 and 1999) [39], population dynamics [40,41], occurrence of edge effects, and a synthesis of environmental patterns collectively organized along a longitudinal profile of the Carioca.

Notwithstanding its modest dimensions - it is actually a moderately sized stream - the Carioca is a meaningful cultural symbol of the heterogeneous matrix that characterizes the urban environment of Rio. As shown on Figure 2, the Carioca watershed presents a geomorphology characteristic of the southeastern coast of Brazil: a coastal plain, dotted and framed by isolated hills and promontories, an inland plain along the river path; gentle slopes that, in this watershed, range approximately from 25 meters to 60 meters above sea level; very steep slopes from 60 to 430 meters, comprising a gradient rupture zone; and a suspended valley, which lies up to 565 meters along the watershed axis, reaching more than 700 meters above sea level at its highest peak (Corcovado). A late-secondary rainforest remains fairly well preserved in the uppermost portion of the watershed, despite strong urban growth pressures surrounding Tijuca National Park. However, urban development is progressively advancing up the slopes of the valley, as is occurring throughout the entire Tijuca Massif. 
Figure 2. The Carioca River Watershed [2].

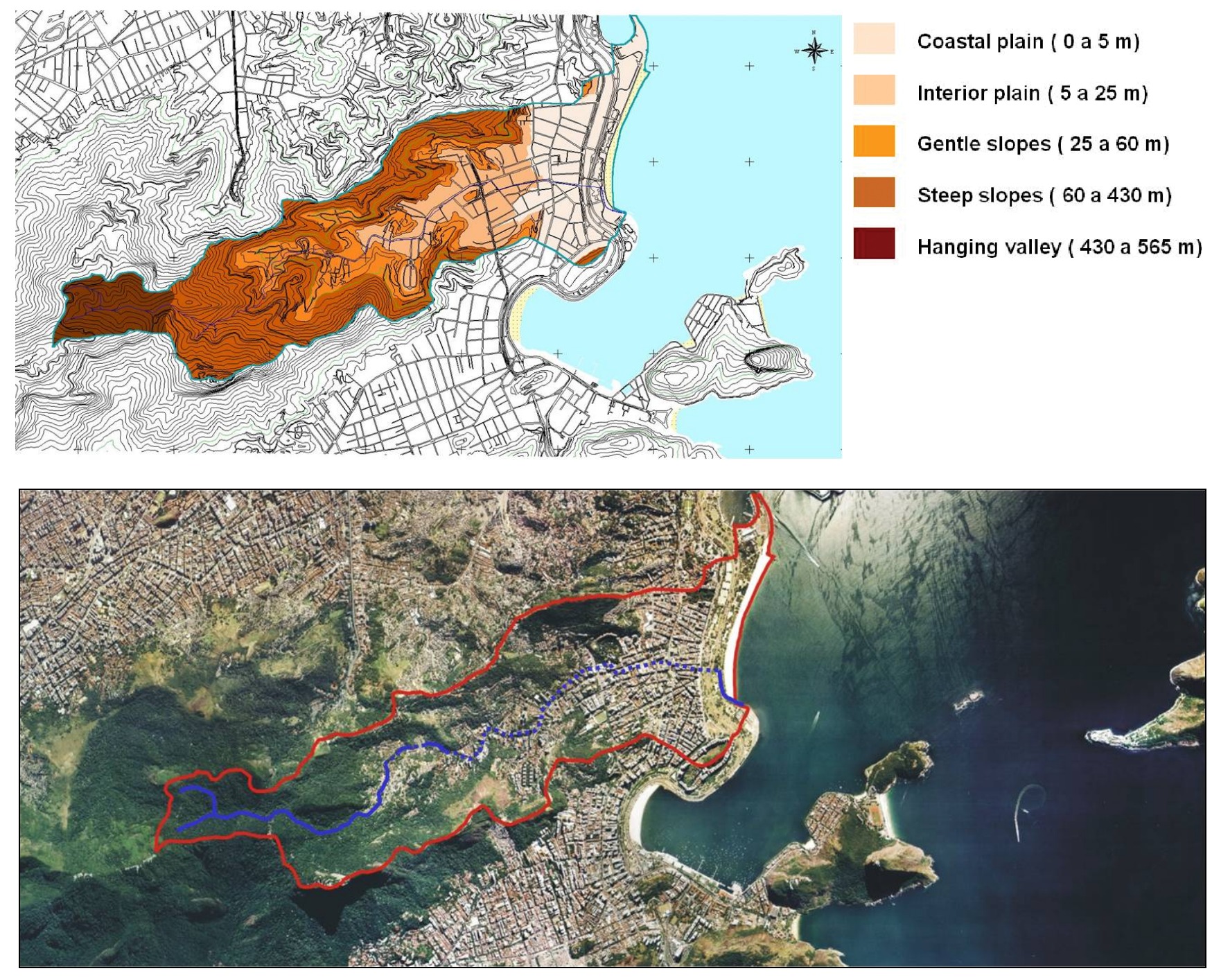


The Carioca River passes through and links heterogeneous landscape mosaics. Originally traversing three primary ecosystems along its length—mountain rainforests, sand banks (restinga) and mangrove wetlands - it now links two contrasting, yet still diverse, landscape mosaics: the mountain rainforest and the urban setting which has been gradually superimposing itself on the former. The landscape of the Carioca River valley immediately informs the relationship between the rainforest and Rio's urban fabric. The river flows along its pathway through different contexts. It rises from two springs high up the southeast slopes of Tijuca Massif. Its upper portion is still preserved within the Tijuca National Park, despite the strong urban pressure at its edges, and the lower river valley shows a typical range of urban impacts. The river crosses the Guararapes favela (a form of slum settlement, usually built on vacant plots of private or government-owned land, located on the steep slopes of Rio de Janeiro city or along its rivers floodplains) and flows channelized through a higher-income residential area and a tourist neocolonial setting. From there, as far as Flamengo Park on the shore of Guanabara Bay, the Carioca is completely buried underground. The only wastewater treatment infrastructure in the watershed, a primary treatment plant, was installed in 2001 by Rio de Janeiro State government at the mouth of the Carioca River. The final reach of the river was covered by a wooden deck by the Rio de Janeiro City Government in 2004 as an attempt to "embellish" Flamengo Park, but effectively blocking visual contact of the river for users in the waterfront park.

The reaches chosen for assessment are representative of the heterogeneous landscape patches found along its way:

- Mountain rainforest (Tijuca National Park)

- Favela (Guararapes community)

- High-income residential area (upper Cosme Velho district)

- Coastal plain (Flamengo Park situated on the filled Guanabara Bay shore)

The purpose of conducting this initial range of assessments was to pinpoint key interrelationships between natural and cultural factors that strongly affect local environmental conditions and gauge the impacts of landscape change. While geological and climatic cycles took millions of years to mold the landscape structure, economic, cultural and landscape management cycles have dramatically re-shaped the Carioca's landscape morphology_ and its underlying processes_ over a relatively brief period of time. Human interventions in the Carioca River valley induced a continuum of transformation that ranges in intensity from the upper Carioca River to its lower reach, piped underground through the densely developed Guanabara Bay shoreline area.

The Carioca River was studied in comparison with four potential reference rivers, an approach widely adopted by fluvial geomorphologists and river restoration specialists [42-45]. Four rivers—-Barra Grande, Barra Pequena, Engenho Novo, and Iconha—were initially considered as potential references for the Carioca, and were visited and surveyed between March and October 2001. The potential reference rivers were considered in consultation with Darcílio Baptista (Environmental Health Promotion and Assessment Laboratory_LAPSA/Biology Department/Fundação Oswaldo Cruz-FIOCRUZ), Timothy Moulton (Ecology Department/Universidade do Estado do Rio de Janeiro-UERJ), and Ana Luiza Coelho Netto (Laboratory of Geo-hydro-ecologyGEOHECO/Geography Department/Universidade Federal do Rio de Janeiro-UFRJ). 
Reference systems can provide a useful basis for assessing changes occurring in the degraded system under investigation, as well as valuable clues to regeneration and resilience criteria. All reference rivers were divided into representative reaches that were assessed, photographed and mapped. Qualitative assessments of landscape patterns, conditions, functions and behaviors, and the main impacts and related sources that affect the Carioca and the potential reference rivers were accomplished in the field. The techniques employed were adapted to accommodate watershed variations and local particularities in order to determine more effectively the key interrelationships among the natural and cultural factors affecting environmental quality and sustainability.

All upstream reaches of the five rivers have similarities, and their original characteristics are fairly well preserved. Carved in Precambrian gneiss and granite, the upper Carioca and the other upper reaches studied have steep rock escarpments, with an abundance of large boulders and cobbles over pebble-sized particles within a non-stratified sandy-clayey soil matrix. In the majority of the upper reaches studied, clusters of climax rainforest are still preserved inside a rainforest matrix of variable (more often advanced) succession stages of development, despite different levels of human pressure in the surroundings. They all contribute to the watersheds as second and third-order streams, and rise above and cross a still-intact Atlantic rainforest mosaic, with all functioning as natural transportation channels, showing different degrees of gradient rupture zones along their longitudinal landscape profiles. Due to its characteristics, the upper Iconha reach was chosen as the main reference reach for research purposes.

The southeastern Brazil Atlantic rainforests are currently formed by patches in varying stages of ecological succession, where clusters of the climax forest can still be found. The riparian vegetation does not present a significant variation in species composition compared with the entire rainforest mosaic within the same gradient. However, along the longitudinal profile of the studied stream corridors, vegetation composition changes considerably, both in response to ecological and human-induced factors. The result is a non-stratified matrix that is in direct response to the high energy flows of southeastern Brazil mountainous streams.

Surrounding land uses strongly influence the degree of preservation of these rivers. The major variability occurs in the lower reaches, where varying degrees of human-induced changes have completely altered stream conditions along some reaches. However, impacts travel up the gradient, against the flow, influencing environmental quality upstream. The level of response and resilience of these rivers to natural events varies according to the scale of previous human-induced alterations. Of all five rivers, the Carioca is the most jeopardized, due to the urban impacts that affect this river.

One of the tools employed to assess alterations in the Carioca River valley landscape and ecological conditions draws on previous techniques: the SVAP — Stream Visual Assessment Protocol, developed by the United States Department of Agriculture's Natural Resources Conservation Service [37] -and the RCE - Riparian, Channel, and Environmental Inventory for Streams in the Agricultural Landscape, developed by Petersen [38]. Rapid assessment protocols have been developed as simple and cost-effective "first-cut" techniques to evaluate the quality and integrity of freshwater ecosystems. The Stream Visual Assessment Protocol (SVAP) relies on visual cues to assess qualitatively stream ecological conditions compared to least-impacted reference conditions. Scores from all attributes are averaged to calculate an overall score, which can be used to make inter-site comparisons, to monitor reaches over time, and to leverage further, more in-depth study. The Riparian, Channel, and 
Environmental Inventory (RCE) was developed for assessing physical and biological conditions of small streams in agricultural landscapes. Although developed for agricultural contexts, this protocol offers elements that are relevant to urban rivers. While not commonly applied in urban settings, these protocols are helpful tools to observe and describe geo-hydro-ecological patterns, as well as to assess human-induced changes that affect stream conditions.

Field experiences and preliminary results in the rivers under investigation demonstrated that the application of the stream visual assessment protocols tested (SVAP and RCE) needed adjustments to be transferable to Brazilian neotropical streams and rivers. More specifically, they needed to be adapted in terms of content and design. The development of an adapted protocol was informed by discussions with local researchers, Darcílio Baptista (LAPSA/FIOCRUZ), Ana Luiza Coelho Netto (Geography Department/Universidade Federal Rio de Janeiro-UFRJ), and Rogério Ribeiro de Oliveira (Interdisciplinary Center of the Environment/Geography Department/Pontifícia Universidade Católica do Rio de Janeiro-PUC-RIO).

From January to October 2001, SVAP and RCE were applied to the five rivers under study. Reaches were chosen, based on their dominant land use, including rainforests, regular urban settlements, favelas, and an urban recreational park. At least three different participants conducted the SVAP and RCE protocols at each assessment. After the application of the two protocols, discussions with the survey participants helped to build a rationale based on the collective experiences in the field. Comments were registered in a research diary, with special emphasis on the usability and consistency of both inventories.

The main concern was that protocols developed for North American and European non-urban environments were not fully translatable to Brazilian urban environments, particularly in terms of ecological and urban infrastructure patterns. Four main factors distinguish SE-Brazilian rivers from the types of rivers for which SVAP and RCE have apparently been designed:

- Impact type: urban vs. agricultural;

- Broad environmental region: tropical vs. temperate;

- Landscape position: mountains $v s$. plains;

- Urban infrastructure: presence of domestic sewage along the river path versus sewage treatment along the river path.

Both SVAP and RCE were applied as valuable bases to build a more regionally appropriate protocol to assess landscape change and environmental conditions along selected neotropical streams. Observations of existing conditions found in different reaches were correlated and parameters were gradually adapted, based on existing local conditions and informed by discussions with local experts. In addition to the application of the protocols, efforts were made to photo-document the diverse reaches, conduct basic measurements on physical parameters, survey biological indicators, and document the experiential and spatial characteristics of the rivers. The application of the original protocols to the five mountainous rivers studied was very useful in refining observations of stream conditions and landscape features, correlating different impacts at diverse gradients, and gauging the conditions of the Carioca. In general, both protocols endorsed the primary observations. Since observations were made at the level of the human observer, the heterogeneity of the local landscape 
became progressively clear and some local additional patterns could be identified and added to the protocols.

The identification of major urban and peri-urban impacts that threaten local urban streams served as a primary basis for adapting and hybridizing the protocols to reflect better local conditions. Table 1 shows characteristics in a hierarchical order in terms of scale, significance and scope of associated impacts, from larger landscape conditions to macro-invertebrates. As it evolved, NUSVAP inventoried and assessed:

- broad landscape conditions: land use and channel conditions;

- water conditions: hydrologic alteration, occurrence of sewage discharge and manure presence, aquatic vegetation/nutrient enrichment, occurrence of solid waste disposal, presence of toxicant substances;

- riparian vegetation conditions: riparian zone, canopy cover, composition of riparian vegetation within 10 meters of the channel;

- morphological components: riffles and pools, meanders, pool conditions, barriers to fish movement, retention devices, stream-bank structure, bank undercutting, stream bottom, stony substrate conditions, channel sediment deposition/riffle embeddedness;

- habitat conditions: in-stream fish cover, insect/invertebrate habitat, detritus; and

- aquatic biota presence: macro-invertebrates observed.

Parameters from both techniques were blended to form more detailed indicators that were attuned to local conditions. Local ecological indicators were added to help recognize the local context conditions. Epiphytic species (orchids and bromeliads) are indicators of rainforest in advanced stages of development. Embauba (Cecropia glaziovi), Quaresmeira (Tibouchina granulosa) and the presence of Lianas (vines) serve as indicators of altered forests (forest in primary and secondary stages of development). Banana plantations and invasive grasses (Panicum maximum and Melinis minutiflora) are indicators of more threatened disturbances. To ensure consistency, all parameters were pilot-tested and rated again for each of the Carioca and Iconha reaches from October to December 2001. The scoring method chosen was modified from the one proposed in SVAP [37], on a condition scale from 1 (worst) to 10 (best), allowing for rating of in-between conditions of some parameters. The ratings were then totaled to provide a final ranking. 
Table 1. Neotropical Urban Stream Visual Assessment Protocol (NUSVAP).

\begin{tabular}{|c|c|c|c|c|c|c|c|c|}
\hline $\begin{array}{l}\text { Undisturbed original ecosystem, consisting of } \\
\text { forests, wetlands, or coastal ecosystem } \\
\text { vegetation (restingas and mangroves). } \\
\text { Presence of walking trails. }\end{array}$ & \multicolumn{2}{|c|}{$\begin{array}{l}\text { Preserved forests, wetlands, or } \\
\text { coastal ecosystem vegetation } \\
\text { (restingas and mangroves) with } \\
\text { access for visitors. } \\
\text { Presence of roads and/or railroads. }\end{array}$} & \multicolumn{2}{|c|}{$\begin{array}{l}\text { Residential use with adequate } \\
\text { infrastructure (including sewage } \\
\text { system) with patches of original } \\
\text { ecosystem vegetation still present. } \\
\text { Grasses, banana plantations or } \\
\text { sparse occurrence of crops with } \\
\text { signs of pesticide use. }\end{array}$} & \multicolumn{2}{|c|}{$\begin{array}{l}\text { Residential or mixed use } \\
\text { (residential, commercial, industrial) } \\
\text { with inadequate or damaged } \\
\text { infrastructure. } \\
\text { Eucalyptus plantations and sparse } \\
\text { occurrence of exotic grasses or crops } \\
\text { with signs of pesticide use. } \\
\text { Livestock raising (chickens, pigs, } \\
\text { and cattle) mixed with row crops } \\
\text { within the immediate riparian zone. }\end{array}$} & \multicolumn{2}{|c|}{$\begin{array}{l}\text { Widespread occurrence of } \\
\text { exotic grasses or crops with } \\
\text { signs of pesticide use. } \\
\text { Residential or mixed use } \\
\text { (residential, commercial, } \\
\text { industrial) without any } \\
\text { infrastructure. }\end{array}$} \\
\hline 10 & & 7 & 6 & 5 & 4 & 3 & 2 & 1 \\
\hline \multicolumn{9}{|l|}{ 2. Channel condition } \\
\hline $\begin{array}{l}\text { Natural channel. } \\
\text { No structures or dikes. No evidence of } \\
\text { downcutting or excessive lateral cutting. No } \\
\text { signs of disturbance caused by free access to the } \\
\text { stream. }\end{array}$ & \multicolumn{2}{|c|}{$\begin{array}{l}\text { Evidence of past channel alteration, } \\
\text { but with significant recovery of } \\
\text { channel and banks. Any dikes or } \\
\text { levies are set back to provide access } \\
\text { to an adequate flood plain. } \\
\text { Human/animal activity causing } \\
\text { minor disturbances. }\end{array}$} & \multicolumn{2}{|c|}{$\begin{array}{l}\text { Altered channel. } \\
<50 \% \text { of the reach with riprap } \\
\text { and/or channelization. } \\
\text { Excess aggradation, braided } \\
\text { channel. Dikes or levees restrict } \\
\text { flood plain width. } \\
\text { Intense human/animal activity } \\
\text { causing considerable disturbances. }\end{array}$} & \multicolumn{2}{|c|}{$\begin{array}{l}\text { Channel is actively down } \\
\text { cutting or widening. } \\
>50 \% \text { of the reach with riprap or } \\
\text { channelization. Dikes or levees } \\
\text { prevent access to the flood plain. } \\
\text { Visual access to the stream still } \\
\text { preserved. }\end{array}$} & \multicolumn{2}{|c|}{$\begin{array}{l}\text { River buried underground. } \\
\text { No access to the river is } \\
\text { possible. }\end{array}$} \\
\hline 10 & & 7 & 6 & 5 & 4 & 3 & 2 & 1 \\
\hline \multicolumn{9}{|l|}{ 3. Hydrologic alteration } \\
\hline \multicolumn{2}{|c|}{$\begin{array}{l}\text { No dams, no water withdrawals, no dikes or other } \\
\text { structures affecting flow regime or limiting the stream } \\
\text { access to the floodplain. }\end{array}$} & \multicolumn{2}{|c|}{$\begin{array}{l}\text { Withdrawals, although present, do not affect } \\
\text { flow regime and/or available habitat for biota. }\end{array}$} & \multicolumn{2}{|c|}{$\begin{array}{l}\text { Withdrawals significantly affect flow regime } \\
\text { and/or available habitat for biota. }\end{array}$} & \multicolumn{3}{|c|}{$\begin{array}{l}\text { Withdrawals, channelization or piping } \\
\text { have caused complete alteration of flow } \\
\text { regime and severe loss of habitat, } \\
\text { severely affecting aquatic biota. }\end{array}$} \\
\hline 10 & & 7 & 6 & 5 & 4 & 3 & 2 & 1 \\
\hline
\end{tabular}


Table 1. Cont

\begin{tabular}{|c|c|c|c|c|c|c|c|c|c|}
\hline \multicolumn{10}{|c|}{ 4. Occurrence of sewage discharge and presence of manure } \\
\hline \multicolumn{2}{|c|}{$\begin{array}{l}\text { No wastewater or stormwater discharge. } \\
\text { Clear water along the entire reach. } \\
\text { No sewage odor. }\end{array}$} & \multicolumn{3}{|c|}{$\begin{array}{l}\text { Stormwater discharge. Fairly clear or } \\
\text { occasional slightly greenish water at sparse } \\
\text { points of reach. Sporadic occurrence of sewage } \\
\text { odor. }\end{array}$} & \multicolumn{2}{|c|}{$\begin{array}{l}\text { Occasional clandestine wastewater } \\
\text { discharge. } \\
\text { Greenish to pea green water along entire } \\
\text { reach. } \\
\text { Weak but constant sewage odor. } \\
\text { Occasional manure in stream banks. }\end{array}$} & \multicolumn{3}{|c|}{$\begin{array}{l}\text { Constant wastewater discharge. } \\
\text { Gray or brown water along entire reach. } \\
\text { Occurrence of surface scum, sheen or } \\
\text { heavy coat of foam on water surface. } \\
\text { Strong and constant sewage odor. } \\
\text { Frequent manure on banks or in stream. }\end{array}$} \\
\hline 10 & 9 & \multirow{2}{*}{8} & 7 & 6 & 5 & 4 & 3 & 2 & 1 \\
\hline \multicolumn{9}{|c|}{ 5. Aquatic vegetation/Nutrient enrichment } & \\
\hline \multicolumn{2}{|c|}{$\begin{array}{l}\text { Presence of aquatic plant community in moderate } \\
\text { amounts. } \\
\text { Mosses and small patches of algae present. }\end{array}$} & \multicolumn{3}{|c|}{$\begin{array}{l}\text { Algal growth on stream } \\
\text { substrates, few mosses. } \\
\text { Aquatic plants along margins. }\end{array}$} & \multicolumn{2}{|c|}{$\begin{array}{l}\text { Sparse occurrence of mosses and } \\
\text { overabundance of aquatic plants. } \\
\text { Algal blooms clogging stream, especially } \\
\text { during warmer months. }\end{array}$} & \multicolumn{3}{|c|}{ Aquatic vegetation absent. } \\
\hline 10 & 9 & 8 & 7 & 6 & 5 & 4 & 3 & 2 & 1 \\
\hline \multicolumn{10}{|c|}{ 6. Occurrence of solid waste disposal } \\
\hline \multicolumn{2}{|c|}{ No solid waste disposal observed in the entire reach. } & \multicolumn{3}{|c|}{$\begin{array}{l}\text { Occasional and sparse presence of organic } \\
\text { waste, such as food remains, wood and paper. }\end{array}$} & \multicolumn{2}{|c|}{$\begin{array}{l}\text { Constant solid waste disposal in small } \\
\text { amounts on stream banks and streambed } \\
\text { along } \\
\text { reach-plastic bags, cups, bottles, etc. }\end{array}$} & \multicolumn{3}{|c|}{$\begin{array}{l}\text { Constant solid waste disposal on } \\
\text { streambed and banks clogs stream } \\
\text { channel and aggravates flooding events }\end{array}$} \\
\hline 10 & 9 & 8 & 7 & 6 & 5 & 4 & 3 & 2 & 1 \\
\hline \multicolumn{10}{|c|}{ 7. Presence of toxicant substances (scum, oil, odor) } \\
\hline \multicolumn{2}{|c|}{ No noticeable oil film or other toxicant substances. } & \multicolumn{3}{|c|}{$\begin{array}{l}\text { Sparse and occasional occurrence of oil sheen } \\
\text { on water surface. }\end{array}$} & \multicolumn{2}{|c|}{$\begin{array}{l}\text { Frequent occurrence of oil sheen, and } \\
\text { surface scum on water surface. }\end{array}$} & \multicolumn{3}{|c|}{$\begin{array}{l}\text { Continuous occurrence of oil sheen, } \\
\text { surface scum, sheen or heavy coat of } \\
\text { foam on water surface. Strong odor of } \\
\text { chemicals, oil or other pollutants. }\end{array}$} \\
\hline 10 & 9 & 8 & 7 & 6 & 5 & 4 & 3 & 2 & 1 \\
\hline
\end{tabular}


Table 1. Cont.

\begin{tabular}{|c|c|c|c|c|c|c|c|c|c|c|}
\hline \multicolumn{11}{|c|}{ 8. Riparian zone } \\
\hline \multicolumn{2}{|c|}{$\begin{array}{l}\text { Natural vegetation (trees, shrubs, and ground } \\
\text { species) is }>50 \text { meters wide. } \\
\text { No breaks in vegetation, no paved, dirt or } \\
\text { railroads present. }\end{array}$} & \multicolumn{3}{|c|}{$\begin{array}{l}\text { Natural vegetation ranges from } 15 \text { to } \\
50 \text { meters wide. } \\
\text { Paved, dirt or railroads present. } \\
\text { Sparse occurrence of breaks on } \\
\text { vegetation along entire reach. }\end{array}$} & \multicolumn{2}{|c|}{$\begin{array}{l}\text { Natural vegetation ranges from } 5 \\
\text { to } 15 \text { meters wide. Breaks } \\
\text { occurring at intervals of }>50 \\
\text { meters. Signs of natural } \\
\text { regeneration. } \\
\text { Paved, dirt or railroads adjacent to } \\
\text { the river's riparian zone. }\end{array}$} & \multicolumn{2}{|c|}{$\begin{array}{l}\text { Natural or planted vegetation ranges } \\
\text { from } 1 \text { to } 5 \text { meters wide. Breaks } \\
\text { frequent with some gullies and scars } \\
\text { within intervals of } 50 \text { meters. No } \\
\text { signs of natural regeneration. } \\
\text { Introduced vegetation provides some } \\
\text { shade. }\end{array}$} & \multicolumn{2}{|c|}{$\begin{array}{l}\text { Vegetation absent. } \\
\text { Deeply scarred with gullies } \\
\text { along its length. } \\
\text { Filtering function and aquatic } \\
\text { biota severely compromised. }\end{array}$} \\
\hline 10 & 9 & & 8 & 7 & 6 & 5 & 4 & 3 & 2 & 1 \\
\hline \multicolumn{11}{|c|}{ 9. Canopy cover (for streams from first to third order) } \\
\hline \multicolumn{3}{|c|}{$\begin{array}{l}>80 \% \text { of water surface shaded. } \\
\text { Upstream generally well shaded. }\end{array}$} & \multicolumn{3}{|c|}{$\begin{array}{l}\text { From } 50 \% \text { to } 80 \% \text { of water surface in reach } \\
\text { shaded but upstream poorly shaded. }\end{array}$} & \multicolumn{2}{|c|}{20 to $50 \%$ of water surface in reach shaded. } & \multicolumn{3}{|c|}{$<20 \%$ of water surface in reach shaded. } \\
\hline 10 & 9 & & 8 & 7 & 6 & 5 & 4 & 3 & 2 & 1 \\
\hline \multicolumn{11}{|c|}{ 10. Composition of riparian vegetation } \\
\hline \multicolumn{3}{|c|}{$\begin{array}{l}\text { High density of all strata, including native and non- } \\
\text { pioneer high trees, understory trees, shrubs, and } \\
\text { herbaceous plants. Continuous and regular texture of } \\
\text { canopy cover. High density of epiphytic species. }\end{array}$} & \multicolumn{3}{|c|}{$\begin{array}{l}\text { Mixed climax species and late secondary trees, } \\
\text { such as jacatirão, canela-preta, and pau-jacaré } \\
\text { along channel. One of the strata may be not well } \\
\text { represented. Occasional occurrence of exotic } \\
\text { but well adapted tree species, such as jaqueira. } \\
\text { Coarse texture of canopy cover. }\end{array}$} & \multicolumn{2}{|c|}{$\begin{array}{l}\text { Mixed grasses and sparse pioneer trees, such } \\
\text { as green embaúba, and quaresmeira and/or } \\
\text { shrub species. Presence of native (but non- } \\
\text { local) and exotic tree species. }\end{array}$} & \multicolumn{3}{|c|}{$\begin{array}{l}\text { Vegetation consisting of exotic grasses, } \\
\text { such as capim colonião and capim } \\
\text { gordura and few shrubs, such as } \\
\text { cambarás. } \\
\text { Sparse exotic tree species. }\end{array}$} \\
\hline 10 & 9 & & 8 & 7 & 6 & 5 & 4 & 3 & 2 & 1 \\
\hline \multicolumn{11}{|c|}{ 11. Riffles and pools, or meanders } \\
\hline \multicolumn{3}{|c|}{$\begin{array}{l}\text { Distinct, occurring within regular intervals. Occurrence of } \\
\text { riffles relatively frequent. Placement of boulders provides } \\
\text { "naturally constructed" meanders. }\end{array}$} & \multicolumn{3}{|c|}{$\begin{array}{l}\text { Irregularly spaced. Occurrence of riffles and } \\
\text { meanders infrequent. }\end{array}$} & \multicolumn{2}{|c|}{$\begin{array}{l}\text { Long pools separating short and sparse } \\
\text { riffles, meanders absent. } \\
\text { Although channelized, streambed conserves } \\
\text { natural condition. }\end{array}$} & \multicolumn{3}{|c|}{$\begin{array}{l}\text { Generally all flat water. Meanders, } \\
\text { riffles and pools absent. Artificial } \\
\text { streambed and banks. }\end{array}$} \\
\hline 10 & 9 & & 8 & 7 & 6 & 5 & 4 & 3 & 2 & 1 \\
\hline
\end{tabular}


Table 1. Cont.

\section{Pools}

\begin{tabular}{l|l}
\hline $\begin{array}{l}\text { Deep and shallow pools } \\
\text { abundant, with a mix of substrate materials. }\end{array}$ & Pools present, but shallow and not abundant.
\end{tabular}

Shallow pools with the entire bottom

discernible. Presence of only one type (fine)

substrate material.

\begin{tabular}{|c|c|c|c|c|c|c|c|c|c|}
\hline \multirow{2}{*}{10} & & & & \\
\hline & 9 & 8 & 7 & 6 & 5 & 4 & 3 & 2 & 1 \\
\hline \multicolumn{10}{|c|}{ 13. Barriers to fish movement } \\
\hline \multicolumn{2}{|l|}{ No artificial barriers. } & \multicolumn{3}{|c|}{$\begin{array}{l}\text { Seasonal water withdrawals inhibit movement } \\
\text { within the reach. }\end{array}$} & \multicolumn{2}{|c|}{$\begin{array}{l}\text { Drop structures, culverts, dams or diversions } \\
(>0.30 \text { meters } / 1 \text { foot drop) within } 5 \mathrm{kms} \\
\text { downstream of the reach. }\end{array}$} & \multicolumn{3}{|c|}{$\begin{array}{l}\text { Drop structures, culverts, dams, or } \\
\text { diversions } \\
\text { ( }>0.30 \text { meters } / 1 \text { foot drop) within or } \\
\text { upstream the reach. }\end{array}$} \\
\hline 10 & 9 & \multirow[t]{2}{*}{8} & 7 & 6 & 5 & 4 & \multirow[t]{2}{*}{3} & 2 & 1 \\
\hline \multicolumn{8}{|c|}{ 14. Natural retention devices } & & \\
\hline \multicolumn{2}{|c|}{ Channel with rocks, old logs and snags firmly set in place. } & \multicolumn{3}{|c|}{$\begin{array}{l}\text { Rocks, old logs and snags present, but } 1 / 3 \\
\text { filled with sediment. }\end{array}$} & \multicolumn{2}{|c|}{$\begin{array}{l}\text { Natural retention devices loose, moving with } \\
\text { floods. }\end{array}$} & \multicolumn{3}{|c|}{ Few or no natural retention devices. } \\
\hline 10 & 9 & 8 & 7 & 6 & 5 & 4 & 3 & 2 & 1 \\
\hline \multicolumn{10}{|c|}{ 15. Stream bank structure } \\
\hline \multicolumn{2}{|c|}{$\begin{array}{l}\text { Banks stable; rock and soil held firmly by ground } \\
\text { vegetation, shrubs and tree roots. } \\
>33 \% \text { of eroding surface area of banks in outside bends is } \\
\text { protected by roots that extend to the base-flow elevation. }\end{array}$} & \multicolumn{3}{|c|}{$\begin{array}{l}\text { Banks moderately stable, but loosely held by } \\
\text { ground vegetation, shrubs and tree roots. } \\
<33 \% \text { of eroding surface of banks in outside } \\
\text { bends is protected by roots that extend to the } \\
\text { base-flow elevation. }\end{array}$} & \multicolumn{2}{|c|}{$\begin{array}{l}\text { Banks unstable, comprised of loose soil held } \\
\text { by sparse shrubs and herbaceous vegetation. } \\
\text { Outside bends are actively eroding (slope } \\
\text { failures apparent). }\end{array}$} & \multicolumn{3}{|c|}{$\begin{array}{l}\text { Straight reaches, inside and outside } \\
\text { edges of bends actively eroding } \\
\text { (numerous mature trees falling into } \\
\text { stream and numerous slope failures } \\
\text { apparent) or banks artificially } \\
\text { constructed in concrete or stone } \\
\text { revetment along entire reach. }\end{array}$} \\
\hline 10 & 9 & 8 & 7 & 6 & 5 & 4 & 3 & 2 & 1 \\
\hline \multicolumn{10}{|c|}{ 16. Bank undercutting } \\
\hline \multicolumn{2}{|c|}{$\begin{array}{l}\text { Little or no evidence or restricted to areas with tree root } \\
\text { support. }\end{array}$} & \multicolumn{3}{|c|}{ Cutting only on curves and at constrictions. } & \multicolumn{2}{|c|}{$\begin{array}{l}\text { Cutting frequent. } \\
\text { Undercutting of banks and roots. }\end{array}$} & \multicolumn{3}{|c|}{$\begin{array}{l}\text { Severe cutting along channel. Banks } \\
\text { falling in. } \\
\text { Artificial banks falling in. }\end{array}$} \\
\hline 10 & 9 & 8 & 7 & 6 & 5 & 4 & 3 & 2 & 1 \\
\hline \multicolumn{10}{|c|}{ 17. Stream bottom } \\
\hline \multicolumn{2}{|c|}{$\begin{array}{l}\text { Stony bottom of several sizes packed together and stable } \\
\text { in place. } \\
\text { Interstices obvious. }\end{array}$} & \multicolumn{3}{|c|}{$\begin{array}{l}\text { Stony bottom of several sizes fairly stable in } \\
\text { place. } \\
\text { Sand and little silt loosely moving with flow. }\end{array}$} & \multicolumn{2}{|c|}{$\begin{array}{l}\text { Bottom of gravel, sand, silt, and/or clay } \\
\text { easily moving. }\end{array}$} & \multicolumn{3}{|c|}{$\begin{array}{l}\text { Uniform bottom of sand-clay loosely } \\
\text { held together or moving with the flow. } \\
\text { Stony substrate scarce or absent. }\end{array}$} \\
\hline 10 & 9 & 8 & 7 & 6 & 5 & 4 & 3 & 2 & 1 \\
\hline
\end{tabular}


Table 1. Cont.

\section{Stony substrate feel and appearance}

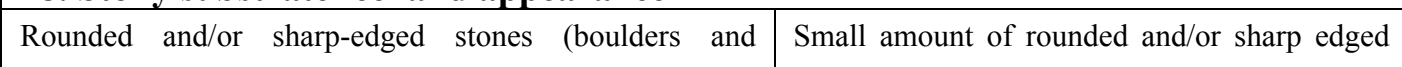

cobbles), at times covered with mosses. stones within slight sandy matrix.
Sparse and sporadic occurrence of sharp-

edged stones within chunks of sandy-clayey matrix.
Bright and sharp-edged stones.

Rocks not deeply embedded with black undersides-indicators of low dissolved oxygen or anaerobic conditions.

Large amounts of non-stratified soil matrix falling into streambed common.

\section{\begin{tabular}{|c|c|c|}
\hline 10 & 9 & 8 \\
\hline
\end{tabular}}

Little or no channel enlargement resulting from sediment accumulation.

Gravel or cobble particles are $<20 \%$ embedded.

Sparse occurrence of coarse stones

and well-washed debris present

Little fine matrix.

Gravel or cobble particles are 20 to

$30 \%$ embedded.

\begin{tabular}{|c|c|c|c|c|c|c|c|c|c|}
\hline & & \multicolumn{2}{|c|}{$30 \%$ embedded. } & & & \multicolumn{2}{|c|}{$75 \%$ embedded. } & & \\
\hline 10 & 9 & 8 & 7 & 6 & 5 & 4 & 3 & 2 & 1 \\
\hline \multicolumn{10}{|c|}{ 20. In-stream fish cover presence } \\
\hline \multicolumn{2}{|l|}{$>7$ cover types } & \multicolumn{2}{|c|}{6 to 7 cover types } & \multicolumn{2}{|c|}{4 to 5 cover types } & \multicolumn{2}{|c|}{2 to 3 cover types } & \multicolumn{2}{|c|}{ None to 1 cover type } \\
\hline 10 & 9 & 8 & 7 & 6 & 5 & 4 & 3 & 2 & 1 \\
\hline
\end{tabular}

Cover types: logs/large woody debris, deep pools, overhanging vegetation, boulders/cobble, riffles, undercut banks, thick root mats, dense macrophyte beds, isolated/backwater pools, other.

\section{Insect/invertebrate habitat}

At least 5 types of habitat available. Habitat is at a stage to allow full inset colonization (woody debris and logs not freshly fallen).

\section{3 to 4 types of habitat.}

Some potential habitat exists, such as

overhanging trees that provide habitat but have not yet entered the stream.
Sediment bars or clusters of sand and silt common.

Gravel or cobble

constrictions and bends.

Deposition on pools prevalent.

Gravel or cobble particles are 50 to

Gravel or cobble

Cover types: Fine woody debris, submerged logs, leaf packs, undercut banks, cobble and boulders covered by mosses, and coarse gravel. Other:

\section{Woody debris and organic detritus}

\begin{tabular}{|l|l}
\hline Abundant, mainly consisting of leaves and coarse woody & Leaves and woody debris present but not
\end{tabular}

debris within small amounts of sediment.

\section{abundant.}

Coarse and fine organic matter without sediment.

\section{1 to 2 types of habitat.}

The substrate is often disturbed, covered, or removed by high stream velocities and scour or by sediment deposition.
Zero to 1 type of habitat. Origina

substrate completely altered.

\begin{tabular}{|l|l|l}
3 & 2 & 1 \\
\hline
\end{tabular}

7

\begin{tabular}{l|l}
7 & 6 \\
\hline
\end{tabular}

None; scarce leaves or woody debris, coarse

and/or fine organic matter with sediment.

ine anaerobic sediment, no coarse natural debris.

\begin{tabular}{|l|l|l|}
\hline 5 & 4 & 3 \\
\hline
\end{tabular}


Table 1. Cont.

\section{Macro-invertebrates observed}

\section{Community dominated by}

Group I (pollution intolerant) species with good species diversity.

Examples include water penny larvae, dobsonfly larvae, non-net spinning caddis flies, mayflies, stoneflies, and hellgrammites.

\begin{tabular}{|cccc|}
\hline \multicolumn{1}{|l}{} & & \\
\hline \multicolumn{2}{|l}{ Overall score (total divided by number of elements scored) } & \\
\hline Class & Score & Evaluation & Color \\
\hline A & $>9.5$ & Excellent & Blue \\
\hline B & $7.5-9.4$ & Good & Green \\
& & & \\
\hline C & $5.1-7.4$ & Fair & Yellow \\
& & & Red \\
\hline D & $<5.0$ & Poor & \\
\hline
\end{tabular}

Group II (facultative) species such as damselflies, dragonflies, aquatic sowbugs, net-spinning caddis

flies, beetle larvae, and crane flies.
Community dominated by
Community dominated by

Group III (pollution tolerant) species such

as midge flies, black flies, leeches,

aquatic earthworms, tubificid worms, and

melanoides (exotic snail).
Extremely reduced number of

species or near absence of

all macro-invertebrates.

Recommended action

Biophysical monitoring for protection of existing conditions.

Selected ecological/biological and morphological re-establishment (soil, planting and aquatic biota restoration and reintroduction) and constant biophysical monitoring for changes.

Major morphological reestablishment and ecological restoration needed (slope profile, vegetation cover, aquatic biota and water restoration); establishment of communitybased restoration programs.

Complete structural reorganization and ecological restoration, where possible; programs to increase community awareness of losses and invite participatory restoration. 
In order to heighten applicability, environmental assessment protocols should be easy to use and flexible. Alterations to the original stream visual assessment protocols considered these requirements by attempting to provide an encompassing and locally adequate technique to evaluate quality and refine the observation of significant stream health parameters. The modifications were designed for high-gradient neotropical urban streams, mainly impacted by sewage discharge and intense human activity in the riparian zone. However, its usability in local peri-industrial as well as in urban-agricultural streams was also predicted through the inclusion of some specific parameters, such as the presence of toxic substances and manure.

Pilot-tests were conducted by two biologists, Darcilio Baptista and Mariana Egler, and the first author in each analyzed reach of the Carioca River and by one biologist, Darcilio Baptista, and the first author in each analyzed reach of the Iconha River. These tests served to validate the protocol adaptations. As recommended in the SVAP protocol, further quantitative validation of NUSVAP's accuracy and additional tests in different settings - including the use of different reference rivers - are recommended to verify the protocol's adequacy in informing the actual conditions of local urban streams.

By examining a selected range of biological and landscape ecology indicators, the previous study phase demonstrated that the main portion of the Carioca watershed under ecological threat is located on the steep slopes of the upper portion of the Carioca watershed. This is where the degradation and retraction of the rainforest has been most dynamic, carrying associated impacts, such as habitat fragmentation and the decline of aquatic biota in terms of species richness and biomass. Urban development and human activities generated an increase in edge-patches on the boundaries of the Tijuca National Park, contributing to the progressive isolation of residual climax forest patches. These results indicated that this phenomenon should be investigated in depth. This reach, as occurs in Tijuca Massif's other watersheds where highly contrasting social clusters (favelas and higher income classes) are found, has been under continuous environmental stress over the last several decades.

\subsection{Methods Applied in Research Phase 2 (2007-2011)}

The results of the research phase 1 (2000-2002) pointed to the need for a refinement in the scale of study to the level of the site plot, a deeper examination of the correlation between popular cultural imprints on the local landscape, and an in-depth investigation of hidden causes and social-environmental conflicts, in order to develop trajectories to mitigate habitat (ecological and social) fragmentation.

Therefore, the methodological approach applied during the second research phase (2007-2011) focused on the identification of morphological and socio-cultural patterns and underlying processes that led to the urban occupation of hillsides in Rio de Janeiro, and investigated the influence of legislation on its configuration over the steep territory of the Tijuca Massif. These inquiries provided insight on the genesis and dynamics of social-environmental conflicts and generated clues that may lead to more sustainable practices in urban hillslope settlements.

The upper Carioca conditions were compared by two other case studies located at the Tijuca Massif in areas subject to intense pressure from the real-estate market and informal land uses. As the research evolved, the interrelatedness between these processes and social, economic and environmental 
conflicts presented implications for urban sustainability. The environmental systems and social clusters targeted for assessment are located in the edge of the rainforest protected by the Tijuca National Park and include: rainforest fragments, a cluster of favelas (Guararapes, Vila Candido and Cerro-Cora communities), and a high-income residential area (upper Cosme Velho district).

The slopes of Rio de Janeiro are characterized by a mosaic of heterogeneous and dynamic landscape patches which compose both the forest and the urban matrix. The forest matrix still prevails on the landscape, despite the urban pressure along its perimeters. As demonstrated by Coelho Netto [46-49], increasing urban development on the slopes is the main factor related to the shrinkage of the rainforest in Rio de Janeiro, which in turns tends to contribute to landslides in every rain event of major intensity. Given this context, this research phase goal was to contribute to an understanding of the processes and patterns of urban occupation over the slopes and disclose their logics and interplays.

The methodological approach applied in this research phase correlated the hillside landscape morphology with the processes of formation, development and sprawl of urban occupation in complementary scales of analysis, and assessed the regulatory legislation that shaped it. Thus, the methodological approach was structured in three areas of analysis:

- Landscape morphology;

- Processes and agents of formation and transformation;

- Influences of regulatory ordinances.

This research phase focused on the occupation process of urban slopes in three scales of analysis, in the light of geo-biophysical, landscape and regulatory aspects, in order to disclose singularities, interdependent relationships, conflicts and contradictions in each level of investigation. Initially, it built on a comparative study of the occupation of the slopes in five Brazilian cities, supported by several workshops sponsored by the Brazilian Landscape Network QUAPA-SEL. The main object of study - the city of Rio de Janeiro-was correlated against four other Brazilian cities-Florianopolis, Vitoria, São Paulo and Belo Horizonte. The analysis deepened in the Rio urban context, focusing three case studies located in watersheds subject to intense urban stress on the Tijuca Massif (see Figure 3):

1. Carioca River watershed, on the eastern slopes of Tijuca Massif;

2. Confluence of the Rainha watershed and the São Conrado watershed, on the South slopes of the Tijuca Massif;

3. Cachoeira River watershed, on the western slopes of the Tijuca Massif.

At each scale, the structure and the dynamics of the landscape were examined from a set of categories of analysis. Parameters and standards of regulation and protection established at the municipal, state and federal government levels were correlated to stress the interdependence and the relationship in and within hierarchical levels. In each level, the specific spatial patterns of occupancy (i.e., high income strata neighborhoods and favelas), as well as the general characteristics of the three urban clusters, were studied and correlated.

The methodological approach also built on several techniques to gauge landscape change and assess landscape conditions, including field surveys conducted between 2008 and 2010, GIS mapping at 1:2000 scale (approved allotment projects of formal settlements and the internal configuration of the 
analyzed favelas); three aerial photographic surveys (November 2008, June and December 2010) and several interwoven matrices analyses.

Figure 3. Analyzed clusters [3].
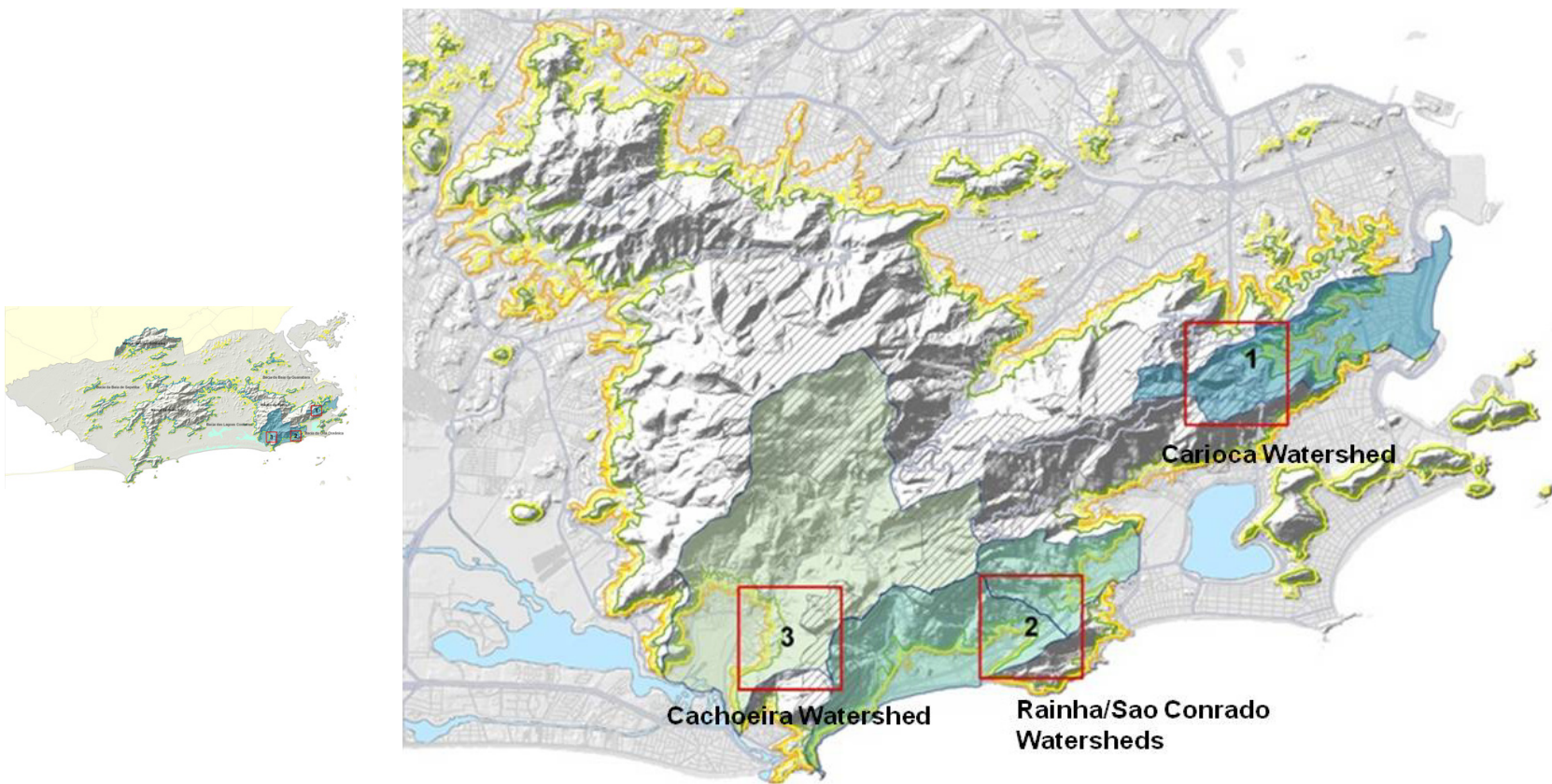

This research phase built up on theoretical and methodological contributions [12,13,15,28,32-35] in order to inform the theory of landscape structure formation and dynamics. Those studies pointed out the direct relationship between the spatial patterns and the landscape processes of configuration and transformation and they demonstrated the importance of conducting analyses at different scales, indicating that information obtained with this procedure might be correlated and extrapolated to other scales. Based on the theoretical and methodological framework cited, the following categories and elements of analysis were established:

- Environmental characteristics: landscape domains; regional and local geomorphology; biomes; altimetry; percentage of urban land in mountainous areas; predominant vegetation communities; watershed characteristics; slope and slope form (horizontal and vertical curvatures);

- Social characteristics: Rio's population dynamics [40,41]; population dynamics on the slopes (Observatorio das Metropoles) [50]; density (inhabitants $/ \mathrm{km}^{2}$ ); building density; GDP per capita; incidence of poverty [51]; Urbanization characteristics: land area; genesis and processes of formation and transformation (beginning of formal and favela occupation); location/position of formal settlements and favelas; vectors of occupation; structure of the occupation; current land uses and past land uses; degrees of illegality; land parceling; architectural types; open spaces characteristics;

- Examination of current and past legislation: land use regulation; environmental protection regulation; zoning.

This approach enabled identification of singularities and common aspects, causes and effects, and provided an understanding of contrasting and interdependent relationships that have guided the 
transformation of the landscape in the hill slopes of Rio de Janeiro, and that constitute the basis of the conflicts in the interface between the city and its urban rainforest. The information gathered in georeferenced thematic maps was systematized in matrices to build a database of the slopes of Rio de Janeiro, to be updated in future studies.

These instruments enabled a blend of qualitative and quantitative data as the basis for a robust understanding of how different components interact in a landscape through time. The summaries were generated by the connections between the matrices of analysis and the mapping process. The initial difficulties of the mapping process were many, due primarily to a lack of an updated cadastral base that includes the internal configuration of the favelas. The 1:2000 scale cadastral base, which shows all buildings in the city, does not include the internal configuration of the favelas. In fact, only peripheral boundaries of these informal communities are delineated, suggesting that the slums are still absent from Rio's urban planning process and that, despite much rhetoric, they continue to be bureaucratized as an illegitimate world apart. This dearth of information led to a laborious process of analysis, ground-truthing, and GIS mapping of the favelas layouts, but spurred updated cadastral mapping through the Approved Allotment Projects (PALs) initiative. The following is a discussion of both phases of the case study of the upper Carioca River watershed. The details of the legislation assessment will be published elsewhere.

\subsection{Assessments and Findings of Research Phase 1 (2000-2002)}

\subsubsection{Biochemical Assessment}

In addition to the application of the visual inventories, biological and chemical assessments were conducted to evaluate the Carioca water quality. Samples were collected at representative reaches of the Carioca at three gauge stations at Tijuca National Park reach (TP), Favela Guararapes reach (FP), and Largo do Boticário reach (LB). The analysis of fecal coliforms was conducted at the laboratories of PABA/UFRJ (Bio-Aquatic Assessment Program, Department of Marine Biology, Federal University of Rio de Janeiro). Data from monitoring efforts conducted in 1991 (FEEMA-Rio de Janeiro State Foundation for Environmental Engineering), 1994 (CEDAE—Rio de Janeiro State Agency of Water and Sewage) and 2001 (FEEMA) were correlated to the data produced by this study.

The results of water quality assessment through biochemical evaluations of 1991, 1994, and 2001 show the progressive decline of the Carioca River water quality during the 1990s. The analyses of biochemical parameters also demonstrate the enormous contrast between the Carioca water quality along its headwaters within the boundaries of Tijuca National Park, and at its mouth in Flamengo Park, where it discharges into the Guanabara Bay.

\subsubsection{Using Macro-Invertebrates as Bio-Indicators of Stream Health}

The purpose of applying biological indicators, in addition to the commonly employed bio-chemical indicators, was to incorporate in this study a more refined measure of environmental quality than is available through visual assessment protocols, since ecological research on macro-invertebrate resilience to human-induced impacts is well developed. The assessments were conducted at the Carioca and Iconha Rivers. Samples were collected at different sites on a single sampling occasion 
between March and June 2001. The survey process was based on the Macro-invertebrate Collection Procedure, adapted from the Volunteer Stream Monitoring: A Methods Manual, developed by EPA in 1997. Macro-invertebrate samples were grouped by degree of tolerance to pollution: pollution sensitive (Group 1), intermediately sensitive (Group 2), and pollution tolerant (Group 3). Subsequently they were grouped by functional category, indicating each group's trophic relation to the environment: collectors, collectors/scrapers, collectors/filterers, scrapers feeding on sediments (algae and organic matter), and shredders feeding on processed leaves and predators. Analysis and results comprise tolerance to pollution, abundance, functional behavior and feeding strategies, community composition, habitat and suggestions of additional local bio-indicators.

Sampling locations were approached from the downstream end. At each site, three samples were taken from four habitat types or substrates: in riffle areas - riffle litter (Rl) and stones (St) —and in pool areas-leaf packs (Lp) and sand (Sa). Three "jabs" were conducted to achieve a broad variability of substrate types (fast flowing, intermediate, slow flowing, totally processed litter, under-processed/recent leaf packs). Jabs were not combined into one sample, as suggested in the Biosurvey Collection Procedure. They were kept separated. This procedure allowed for subsequent correlation of the macro-invertebrates to their preferred type of habitat, as well as a correlation between eroding and accreting habitats, such as riffles and pools. The Carioca and Iconha samples were sorted, identified, counted and preserved in $80 \%$ ethanol by Mariana Egler in Laboratório de Avaliação e Promoção da Saúde Ambiental/BIO DEPT/IOC/FIOCRUZ, coordinated by Darcílio Baptista. Samples are filed in Baptista's laboratory at FIOCRUZ.

The macro-invertebrate samples from the survey reaches of Carioca and Iconha rivers were grouped and listed in tables by degree of tolerance to pollution: pollution sensitive (Group 1), intermediately sensitive (Group 2), and pollution tolerant (Group 3), as given in the Biosurvey Collection Procedure cited above. Subsequent tables listed the macro-invertebrates found at each reach of the referred rivers grouped by functional category, indicating each group's trophic relation to the environment: collectors, collectors/scrapers, collectors/filters, scrapers feeding on sediments (algae and organic matter), and shredders feeding on processed leaves and predators.

Bio-assessment results along the Carioca and the Iconha rivers corroborate the results of biochemical assessments conducted at the Carioca, allowing further inferences. The correlation between the findings in the Iconha and Carioca provided helpful information about species abundance, composition, tolerance to pollution, habitat, functional behavior and feeding strategies, thus contributing to an assessment of the resilience of each reach against impacts and stressors. The aquatic biota decline gauged during this phase of fieldwork (see Figure 4) appears to be the result of severe alterations in nutrient loading brought by frequent sewage discharges into the river, as well as proximity of roads, removal and fragmentation of the original rainforest, and flow regime alteration caused by water withdrawal structures.

The analyses of biological and biochemical parameters indicate four distinct patterns, suggesting a gradient of degradation that ranges from the Carioca headwaters to the boundaries of Tijuca National Park (TP). Pattern 2: Favela Guararapes (FG). Pattern 3: upper urban fabric (LB), and Pattern 4: lower urban fabric to the mouth of the Carioca, in Flamengo Park (FP), where the river discharges into the Guanabara Bay. 
Figure 4. Carioca River Water Quality [2].

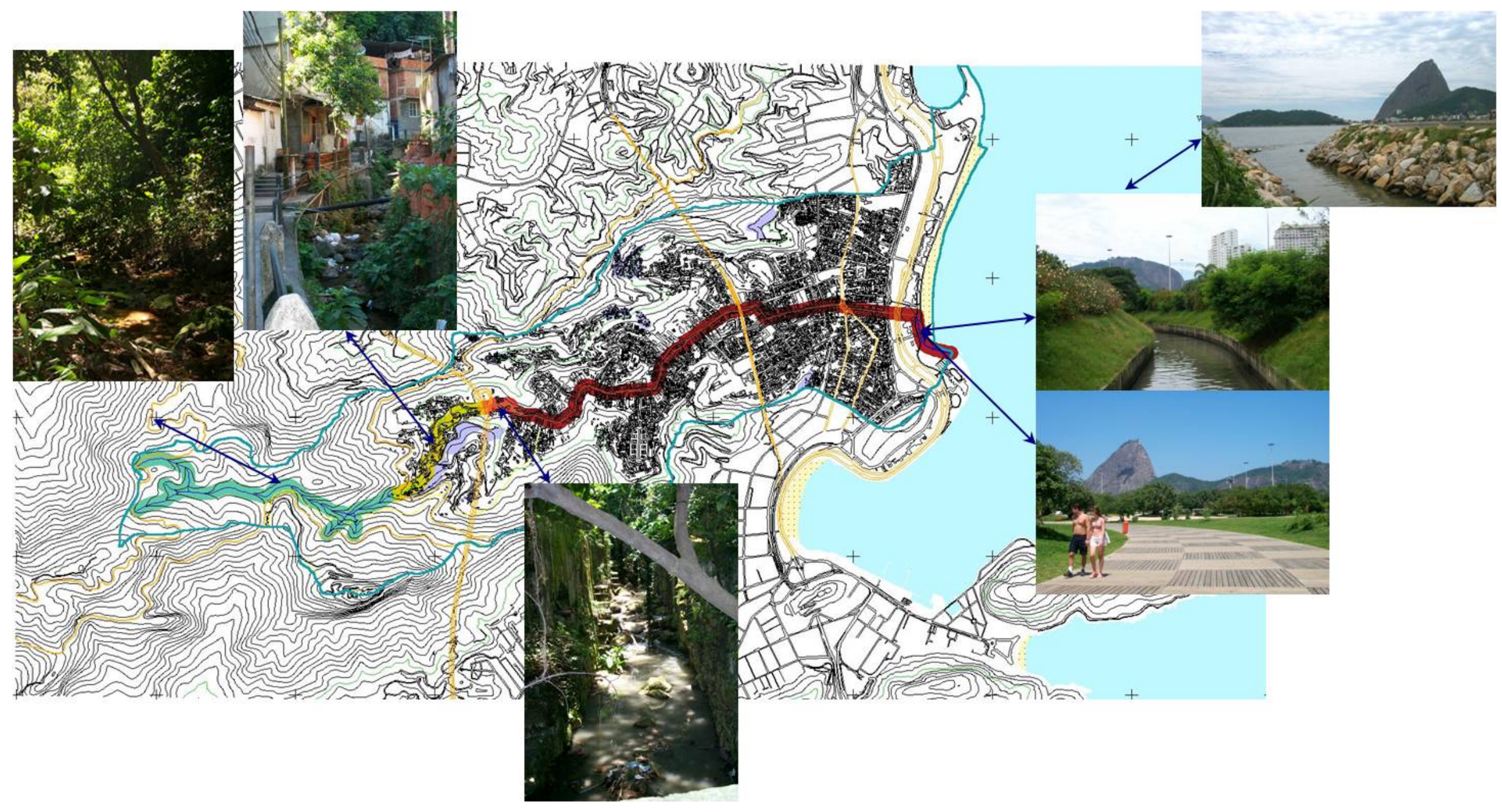




\subsubsection{Other Bio-Physical Parameters of Landscape Change}

\subsubsection{Land Cover}

The results of this survey were combined with GIS mapping and field observations. A series of map layers was prepared at a scale of 1:10,000, including a multi-temporal evolution of land use and vegetation cover (1972, 1984, 1999), population dynamics (1991 and 1996), conservation units, districts and favelas, ecological edge effect, and density and height of built form. Maps were compiled from both primary data collected in the field and local city and university archives, to provide a broad picture of the Carioca watershed, applying and extending methodology of GEOHECO-UFRJ/SMAC-PCRJ 2000 [39]. Mapped patterns were then transferred to the Carioca's longitudinal profile as a means of synthesizing the information (present study, modified from Coutinho [52]. The scale of analysis was expanded to the watershed level by examining aerial photos from 1972, 1984, and 1996 with a stereoscope. The 1999 conditions were gauged examining orthophotos of 1999 (IPP-PCRJ 2000) and field-checked in 2001. The rainforest retraction process since 1972 did not describe a linear trend through time. Although still in progress, since 1984 there has been a slowdown in the rate of rainforest loss in the Carioca watershed. This may be explained by three interconnected factors: the beginning of the Rio de Janeiro reforestation program after 1986, the community-based reforestation efforts in the river valley in the beginning of the 1990s, and the entrenchment of conservation units in the city planning policy in 1985.

\subsubsection{Population Dynamics}

A comparison based on the Carioca River valley population data suggests a correlation between the evolution of the social landscape and the transformation of urban patterns locally. The majority of the Carioca River valley favela population inhabits the upper portion of the watershed, which is also inhabited by higher income classes. As demonstrated by previous studies in the Tijuca Massif [39, among others] and confirmed by the present study, the pattern of urban development along the slopes of the Carioca watershed is characterized by a co-existence of informal favelas and regular development plots that adhere to local legislation, demonstrating that formal urban development and the presence of high- and middle class settlements do not inhibit the expansion of favelas nearby. The favelas of the Carioca River valley are going through a process of spatial condensation. The result is an almost continuous favela territory along the footslopes of the upper Carioca watershed where Guararapes (established 1937), Vila Cândido (established 1931) and Cerro-Corá (established 1941) are now spatially united. The same phenomenon is also in progress in other favelas throughout the city.

\subsubsection{Ecological Edge Effect}

Figure 5 indicates three hierarchic edge strips, delineated, based on the correlation of biological field assessments with land use and vegetation cover, geomorphology, proximity to existing roads, and urban areas, as likely indicators of further development. Edge strips were also associated with the level and type of impacts. For Edge 1, they include the co-existence of urban development, favelas, and 
patches of altered forest; the increase of erosion susceptibility (mainly caused by natural drainage modifications and failures in drainage infrastructure along the roads); the proliferation of shade-intolerant vegetation along the boundaries (mainly lianas); the invasion of exotic species (mainly grasses such as Panicum maximum); occasional burning of remaining vegetation, and; frequent illegal solid waste disposal downhill. For Edge 2, they include the decline of canopy and subcanopy due to fire, wind and light susceptibility of borderline vegetation. For Edge 3, edge effects include natural drainage modifications, pockets of exotic species, and illegal solid waste disposal along the margins of the main access roads to Tijuca National Park.

Figure 5. Edge Effects [2].

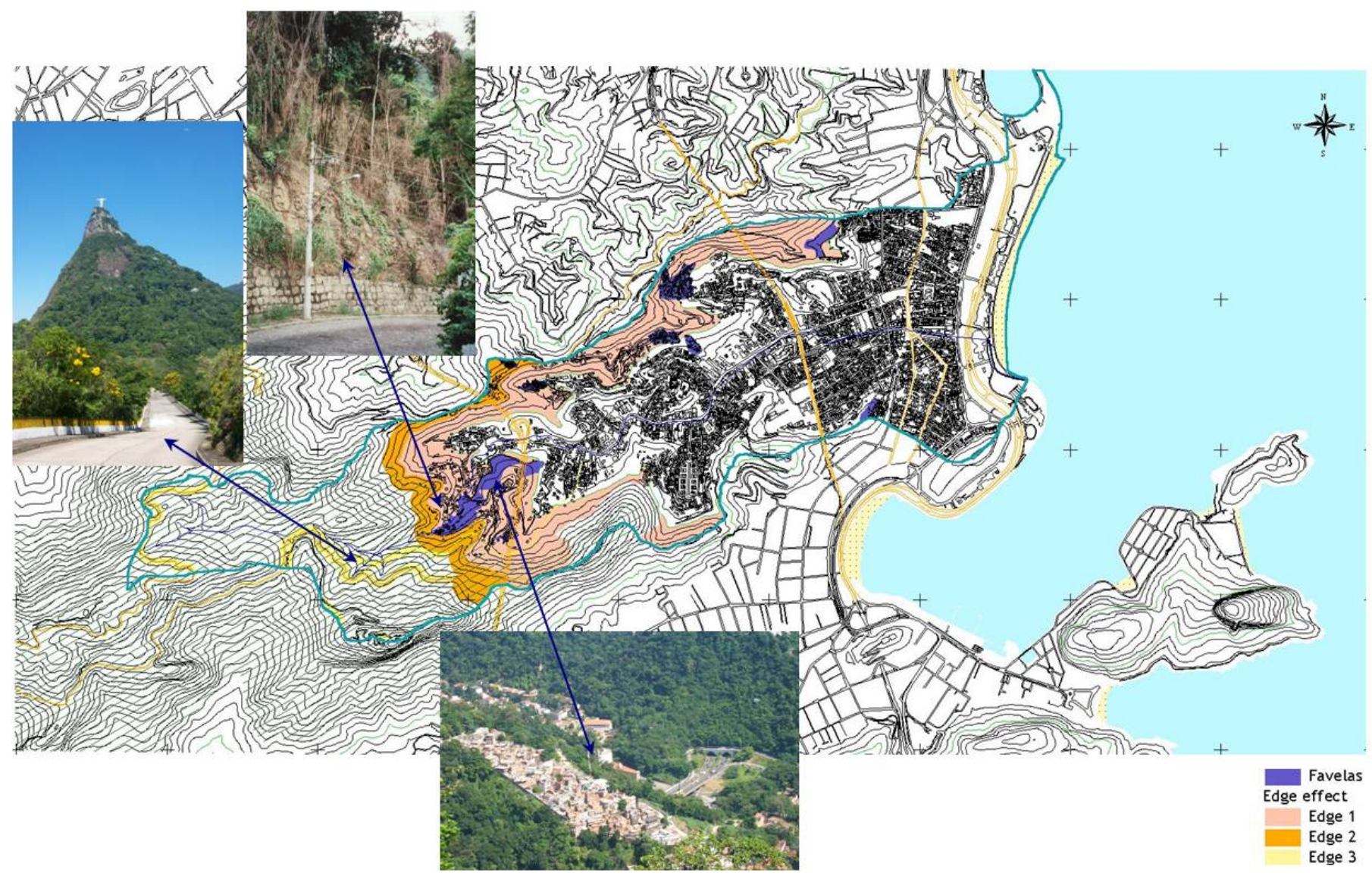

Together, the methods employed in this study provided an integrated picture of numerous factors leading up to, and currently influencing, the ecological and urban conditions of an urban-forest landscape system. The combination of biophysical and water quality characterizations and socio-cultural inquiry provided insight as to how the Carioca River corridor has changed in response to dominant landscape transformations that occurred in the city of Rio de Janeiro. This work also served to evaluate the degree of degradation of the Carioca resulting from human-induced impacts and stressors upon the stream's upper ecosystem as well as to provide some clues for inferring its resilience capacity (see Figure 6 and 7). 
Figure 6. Landscape Patterns [2,53].
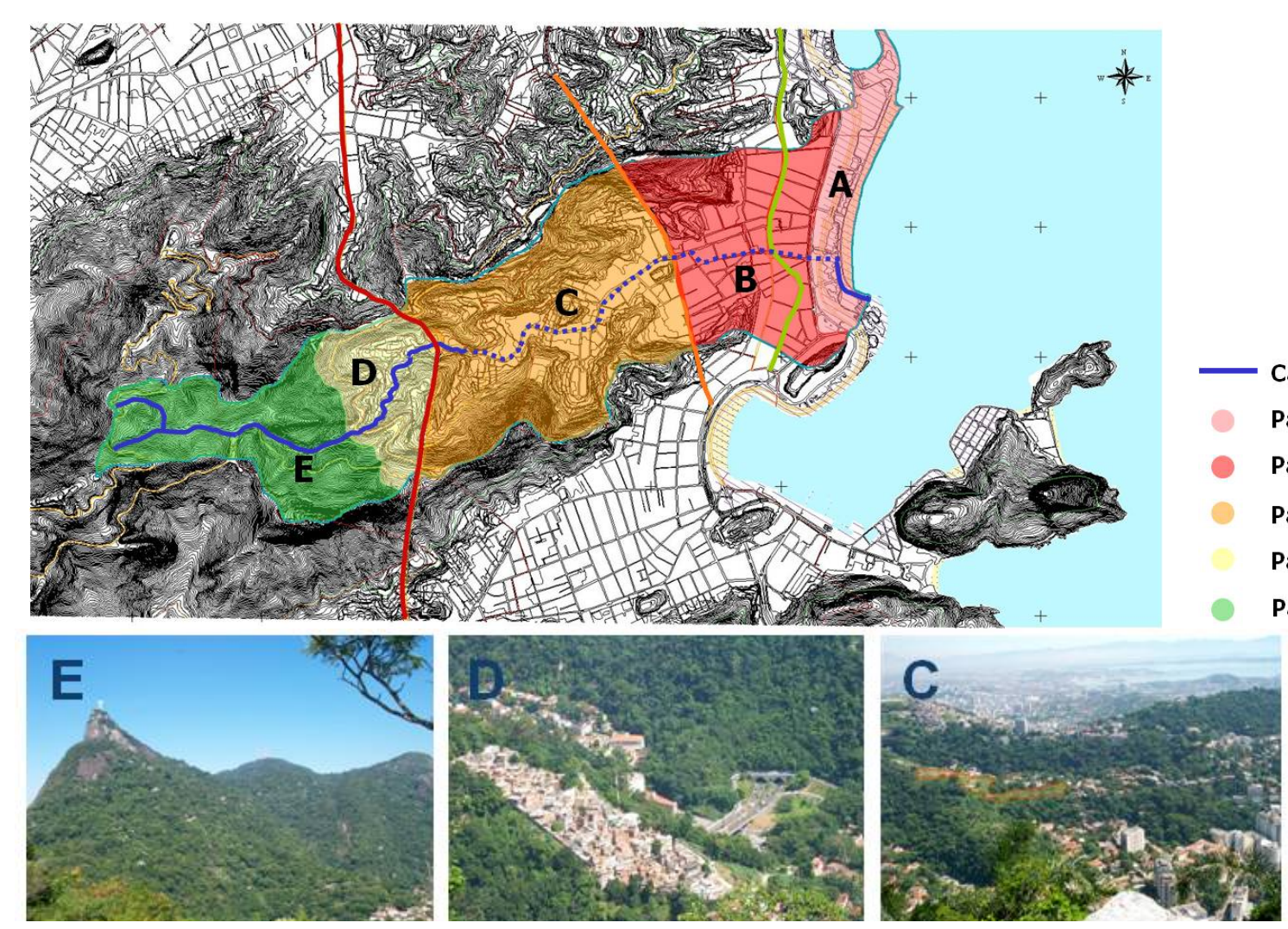

Pattern A: Parque do Flamengo

Pattern B: $\mathbf{3 0 0}$ hab/ha, severely althered conditions, piping

Pattern C: $\mathbf{1 8 0}$ hab/ha, althered conditions, piping

Pattern D: 80 hab/ha, edge effect, channelization

Patterrn E: Parque Nacional da Tijuca, good conditions

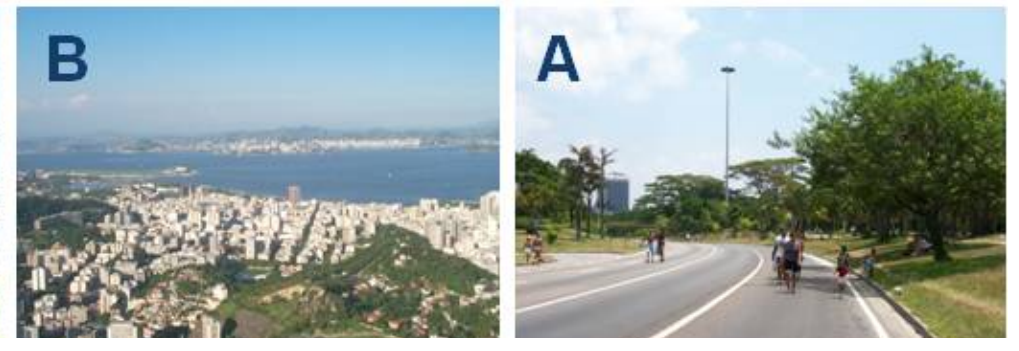


Figure 7. Longitudinal Profile [2].

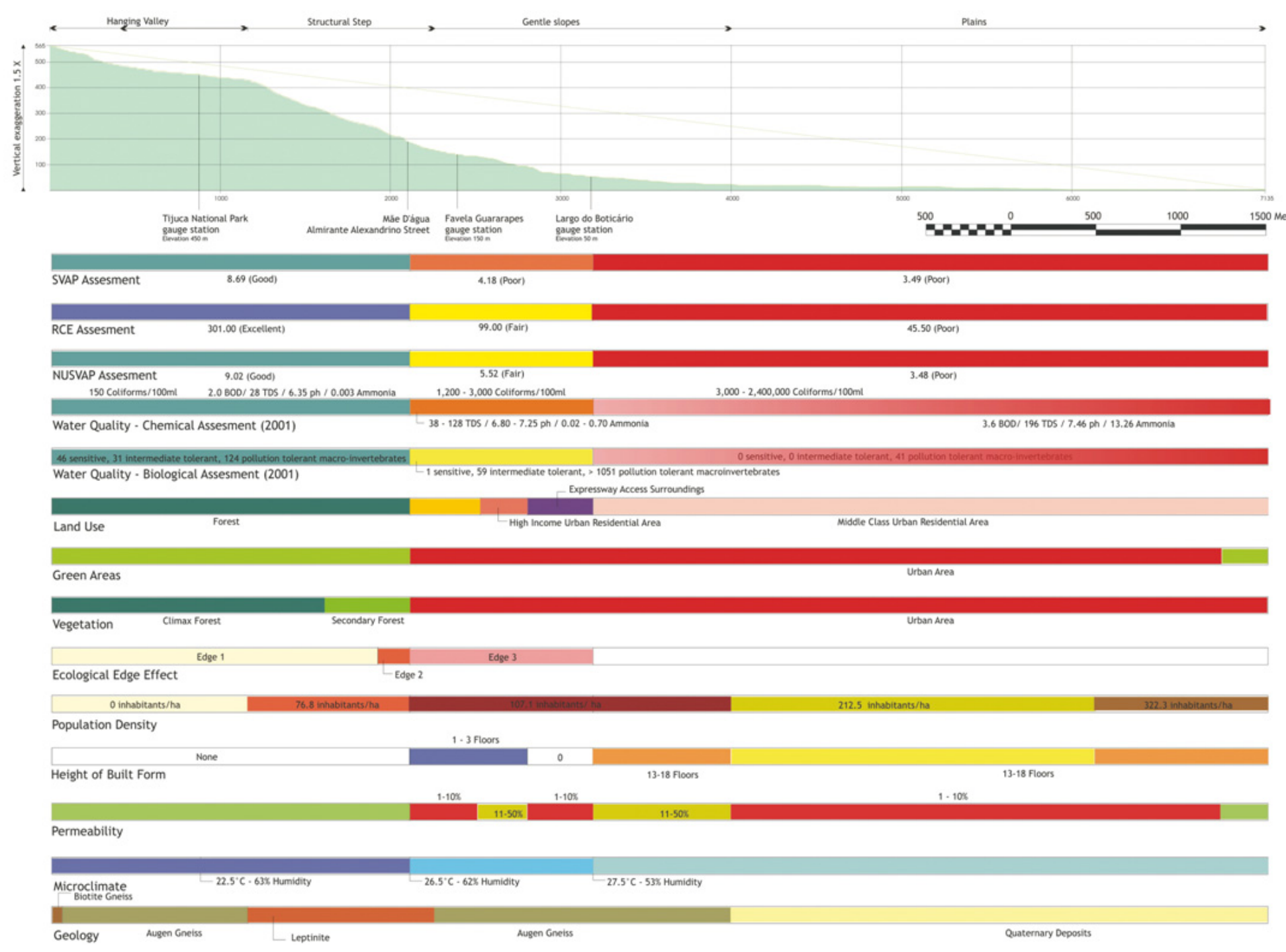


By examining a select range of biological and landscape ecology indicators, this research phase demonstrated that the process of landscape change was especially intense along the area between Cosme Velho and Santa Teresa districts. This reach has been under strong environmental stress in the last few decades. It is in this zone that the retraction of the rainforest has been most dynamic, carrying associated impacts, such as habitat fragmentation and the decline of aquatic biota in terms of species richness and biomass. It is also where highly contrasting social clusters are found side by side (gated higher income communities and favelas).

\subsection{Assessments and Findings of Research Phase 2 (2007-2011)}

\subsubsection{Landscape Dynamics: Links between the Current and Past Landscape Configurations}

The cultural framework focused on Carioca's cultural history, blending archive-based historical research, secondary sources, narrative knowledge and selected key informant semi-structured interviews. Urban settlement began alongside the Carioca River valley bottom and its tributaries. The progressive parceling of existing farms and ranches led to the first urban settlements in this area, registered between 1930 and 1940. The link between the pre-urban setting and the current urban fabric generated a spatial differentiation between the two banks of the Carioca, reflecting the enduring social polarization. The upper Carioca urban fabric in the area that comprises the analyzed reach at Cosme Velho District was mainly set on the grounds of two pre-existing farms. The formal settlements mostly concentrated in the left margin, as the favelas established on the right bank of the river. Investigation of deeds and land titles found no record of official parceling of lands occupied by the slums in the upper Carioca watershed reach under study. Analysis of land ownership surveys of some precincts of the slums was conducted by SMH/PCRJ in the mid-1990s. This revealed that the first nuclei of slums in that area occurred in the late 19th century along the right bank of the Carioca. It was assumed that these nascent favelas were related to the presence of the Alliance Textiles Company that operated in the Carioca valley from 1880 to 1937, as indicated by Cavalcanti [54] and Rezende [55]. Another possibility pointed to a residence permit by the owner of one of the farms, or by the institution that implemented a hospital contiguous with the slums. As described by Abreu [56], private owners used to donate plots to the church or sorority religious institutions to shelter their workers. As suggested by previous researchers, the presence of the working class dates back to the pre-urban period [57,58], suggesting an interwoven relationship between these different strata for many decades. According to Dantas and Senra [58], the first settlers of the Guararapes community occupied the land near an existing water spring in the 1890s. In the 1930s, four nuclei were already installed on the banks of the Carioca River and along the existing roads that led to the area $[57,58]$.

\subsubsection{Current Landscape Configuration Patterns}

\subsubsection{Land Ownership}

Identifying the dominion of the land located on the slopes of Rio de Janeiro city is fundamental for planning and management of this portion of Rio's landscape. Land ownership was identified and mapped, including public land, public land invaded by favelas, private landholdings, and private lands 
invaded by favelas, as shown on Figure 8. Public land predominates on the slopes of the Tijuca Massif due to the existence of the Tijuca National Park and the peripheral forested reserves originating during early land parceling by the then Rio de Janeiro Federal District. Contrary to widespread belief promulgated by the city government and the media, most of the studied slums are situated on private, rather than public, landholdings. The favelas' processes of informal occupation stemmed from a variety of situations, ranging from collective ownership, permitted occupation consented by original owners, to appropriation and administration by religious institutions, to invasion spurred by unfinished processes of legalization of parcelings, to non-implementation of community facilities by the city government.

Figure 8. Land Ownership [3].

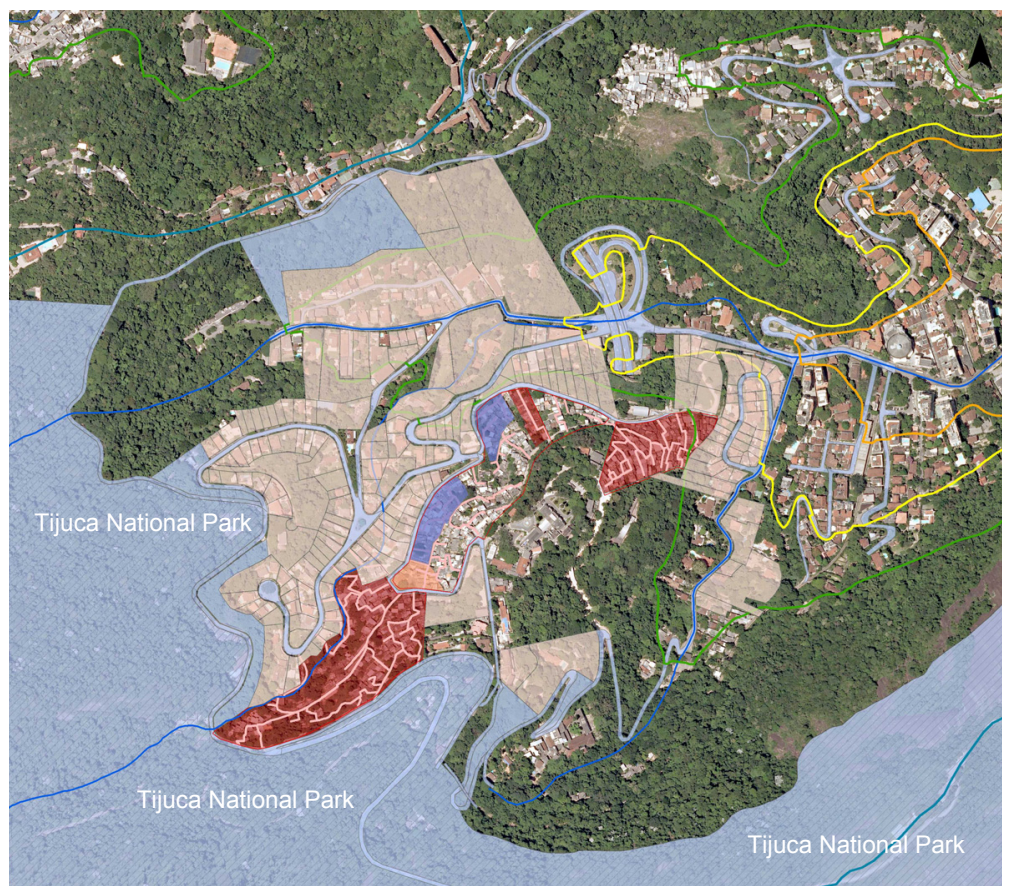

Public land

Invaded public land Private land Collective private land Invaded private land Tijuca National Park

\subsubsection{Parceling}

For analysis purposes, the plots were classified according to categories defined in the Municipal Decree $3800 / 1970$ and its updates: $225 \mathrm{~m}^{2}$ to $360 \mathrm{~m}^{2}, 360$ to $600 \mathrm{~m}^{2}, 600$ to $1000 \mathrm{~m}^{2} ; 1000$ to $5000 \mathrm{~m}^{2}, 5000$ to $10,000 \mathrm{~m}^{2}, 10000$ to $50,000 \mathrm{~m}^{2}, 50,000$ to $100,000 \mathrm{~m}^{2}$, and above $100,000 \mathrm{~m}^{2}$. Most parcels in the upper Carioca watershed date from 1930 to the late 1950s, and have sinuous designs with some inspiration from variations of the Garden City (Cidade Jardim) movement in urban design through the early 1900s. They consist of lots ranging in size from $225 \mathrm{~m}^{2}$ to over $100,000 \mathrm{~m}^{2}$. In the upper Carioca watershed (in the area that comprises the analyzed reach in Cosme Velho District), although small lots predominate, almost half of the urbanized area belongs to a few owners. One single lot of $10,000 \mathrm{~m}^{2}$ occupied $10 \%$ of the total parceled area. Approximately $20 \%$ of the total number of lots range between 360 and $600 \mathrm{~m}^{2}$, and about $40 \%$ range between 1000 and $5000 \mathrm{~m}^{2}$ (see Figure 9). 
Figure 9. Parceling [3].

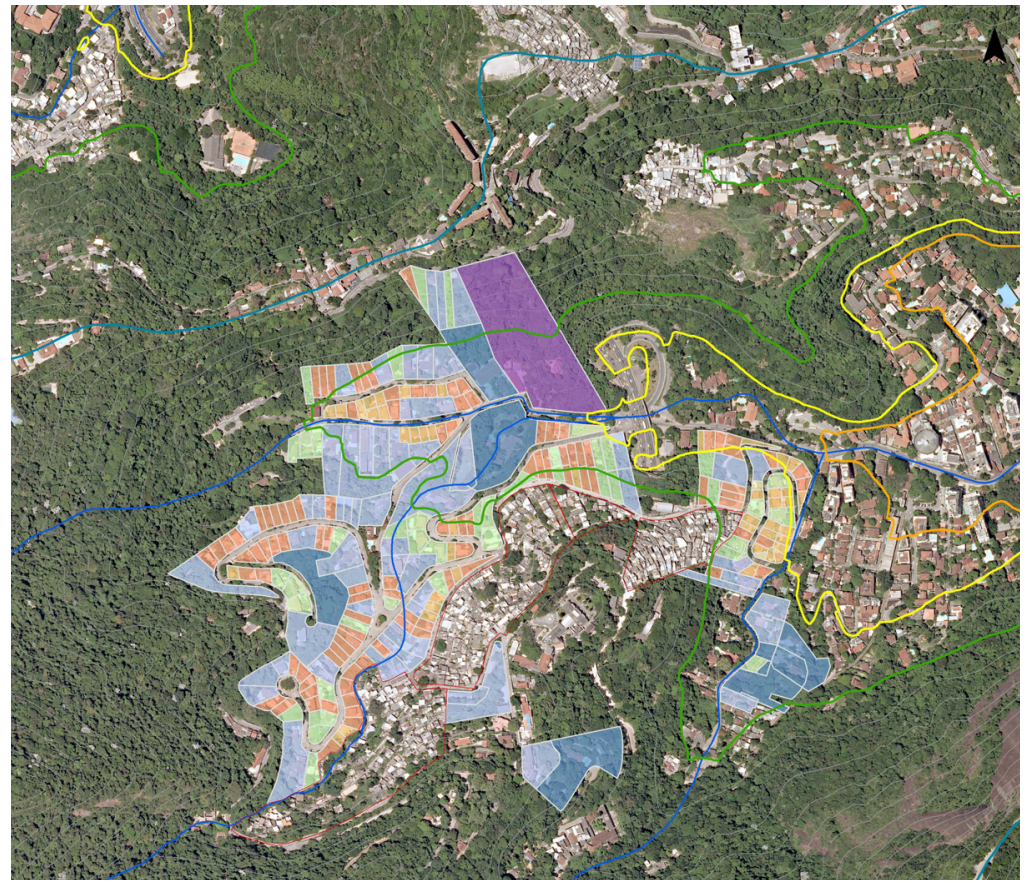

$125-225 \mathrm{~m}^{2}$

225-360 $\mathrm{m}^{2}$ $360-600 \mathrm{~m}^{2}$ $600-1000 \mathrm{~m}^{2}$ $1000-5000 \mathrm{~m}^{2}$ $5000-10000 \mathrm{~m}^{2}$

\subsubsection{Architectural Types and Height of Built Form}

Architectural types in formal settlements are generally a result of architectural and urban planning regulations through time, combined with real estate market patterns, including buildings constructed directly on the ground on plateaus or overcuts or landfills, buildings on stilts or apparent pillars, and vertical buildings with more than four floors. In the slums, they are more a direct consequence of the need to cope with the limited space. To create new spaces, mechanisms such as selling the airspace over slabs and building over collective paths and rocky outcrops are common and widespread. Vertical buildings more than four floors high were found in both formal and informal settlements.

As demonstrated by Silva and Tângari [59], in the dominant scheme of occupation of the slums situated on slopes, buildings are usually staggered in piles, grouped very closely together or overlapping each other, without a clear delineation of parcels. The built forms occur in successive stages occupying a series of terrain cuts and landfills in parallel to, but not linear to, the contour lines. Housing structures tend to be perpendicularly joined by steps or ramps. The process of vertical expansion begins with the installation of concrete slabs, stacking successive new floors, sometimes completely independent of the existing structure, often reserving the use of the higher slab to the original owner. The authors concur with Santos [60] in observing that in areas with rocky outcrops, the buildings are largely supported by stilts or pillars. Some buildings overlap the paths, forming tunnels. In extreme cases, the narrow gaps between buildings allow only the passage of children.

In the upper Carioca watershed (Cosme Velho District), approximately 38\% of the formal buildings have two floors and $27 \%$, three floors. In the analyzed informal settlements, about $32 \%$ of buildings have one floor and $37 \%$, two floors. However, taller buildings (four floors and higher) occur in both formal neighborhoods and favelas. While in formal areas the highest percentage of vertical expansion occurs in areas with an older occupation, in the slums, the percentage of vertical expansion is greater in the most valuable areas, particularly along the valley bottoms. The occurrence of horizontal additions 
and expansions outside the standards set by law was observed both in areas formally occupied and in informal settlements. Enclaves of legal parcelings were observed inside some favelas, originating from incomplete parcel legalization processes. The opposite situation occurs in the fringe between formal and informal settlements, where the existing fabric is gradually absorbed and acquires the characteristics of an informal fabric.

\subsubsection{Land Use}

In terms of land use, formal settlements tend toward monofunctionality, with a strong predominance of residential use and, secondarily, institutional uses (educational, cultural, religious and welfare). In the slums, the picture is quite different. In general, there is a great diversification of land uses, although residential use also predominates. Mixed use is quite impressive, with commercial use on the ground floor and residential use on upper floors. Commercial use mainly concentrates in the main access roads and main pedestrian alleys. Concerning institutional use, public education and religious uses of different orientations predominate.

\subsubsection{Open Spaces}

The open space system associated with Rio's hillsides is extensive. Private and public forest reserves not incorporated with Tijuca National Park deserve special attention, as well as open spaces along the back boundaries of private lots that still retain a dense vegetation cover. The forest reserves not donated or transferred to the government remain under private domain. Both these features play an important role in contributing to environmental quality in the watershed, and enhance carrying and adaptive capacity with regards to both formal and informal urban development. These forest fragments remain from the process of urban occupation and should be treated with special interest in urban planning and environmental protection efforts on the slopes. As shown in Figure 10, linear green corridors support native vegetation mixed with exotic species, enhance ecological connectivity with the protected Tijuca rainforest, and serve as a buffer zone along the urban development - rainforest interface.

Also important, although transitory, are the empty lots in the formal settlements and the slabs in the informal settlements. All these spaces of public or private ownership are flexible enough to perform multiple functions and represent a significant stock of land to augment the buffer zone between the rainforest and urban fabric.

The percentage of open space designated for recreation in the upper Carioca watershed reach under study ranges from $1 \%$ to $2 \%$ of the urban area actually occupied. Although very few in number, they tend to be located along the valley bottoms and at the junction of routes. Some of those squares are simple lawns, with occasional tree cover, without sidewalks or recreational equipment or amenities that invite use. They appear to serve as intentional esthetic devices, or perhaps as spatial relief at the terminus or intersections of several pathways. In any case, they help reduce the urban heat island affect caused by sprawling built form and a low incidence of tree canopy along streetscapes and pathways in both formal settlements and slums. 
Figure 10. Open Space Potential for Enhanced TNP Buffer Zone [3].
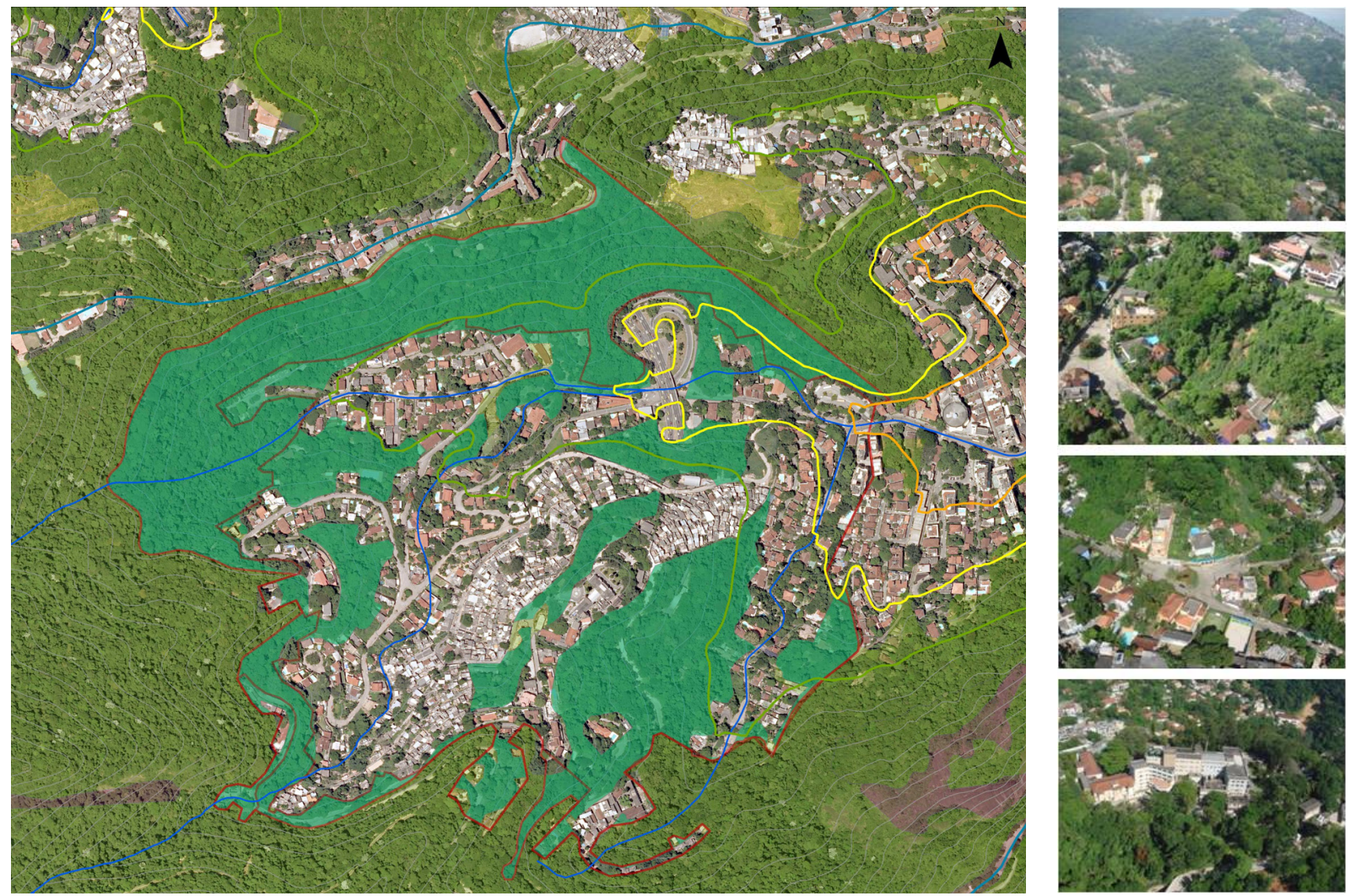

Outdoor recreation and everyday interactions in the formal settlements have become fully privatized, individualized and restricted. Most private spaces in the formal settlements lie out of sight of pedestrians on the streets, suspended and hidden by retaining walls covered with vines. The presence of vegetation on the walls, however, helps to disguise the prevalence of built space over the open spaces in the formal settlements. Similarly, few open spaces are organized and equipped for recreation in the slums under study. In these areas, open spaces for recreation are mainly located at the access points or along the edges of the informal settlements, where space is available. In most cases, these spaces originated through municipal public intervention, such as the Favela-Bairro Project [61]. They tend to be appropriated by the surrounding residents or by the group that controls the portion of the slum territory where they are located. Many of them are used primarily by adults and teenagers. Children tend to attend them accompanied by one of their guardians, after school hours.

In contrast, the narrow collective spaces toward the center of the favelas are shaped through a gradual process of occupation; they are a result of collective production and feature different functions. They are in constant metamorphosis, frequently modified and rearranged, as observed by Andrade [62], Farias [63] and Coelho [64] in other favelas. They are associated with crossing paths or an irregular juxtaposition of buildings, and accommodate a wide variety of recreational activities without formal organization. Daily improvised activities also occur on the many stairs, alleys, cul-desacs, courtyards and slabs. In the favelas, these spaces function commonly as an extension of private space. They offer a sense of security, where children may play on their own with minimal supervision. Open spaces for adult socialization and leisure are usually located next to bars and warehouses that serve as destination points or landmarks, or near public amenities, such as fountains, that become 
animated through daily activities such as clothes washing, walking, and picnicking with family or friends.

This research phase identified a trend towards privatization of collective spaces both in the formal settlements and in the favelas. Open spaces functions and configurations are complementary to those of built space. As for configuration, there is a gradation in terms of privatization of open spaces, with small, restricted-access patios located within larger semi-public or public patios. The smaller spaces have controlled access, restricting use on one hand but assuring identity on the other. They are intermediate spaces that seem to indicate the need for a barrier between the domestic domains and commons, combining the advantages of outdoor spaces with the feeling of protection of the interior private spaces. Flexibility and multifunctionality, governed by daily negotiations (not always friendly) predominate in the open spaces of favelas.

In formal neighborhoods, the prevalence of private open spaces over the public open spaces occurs in terms of diversity of pattern, use and function. While the public open spaces are morphologically simplified and monofunctional, private open spaces have a greater variety in terms of configuration, use and function. Public or collective open spaces in formal areas are mostly very little used in everyday life. In the favelas, open spaces are really limited to the private terraces of buildings. On the other hand, the spaces for collective use, although very scarce, are more flexible, with removable equipment and improvised trailers, benches and chairs, grills and other amenities.

\section{Discussion}

The compilation and cross-referencing of biophysical, ecological and urbanistic parameters assessed during 10 years of longitudinal research in the Carioca River valley reveals the effects of current patterns and processes of on-going urban development, and identifies interactions between the natural and the built environments. It documents the process of urban development and human activities that have generated edge-patches and ecological fragmentation along the boundaries of Tijuca National Park, contributing to the progressive isolation of residual climax forest patches and the decline of the Carioca water quality. The decline in aquatic biota gauged during the fieldwork seems to be the result of excessive nutrient loading from frequent raw sewage discharges into the river, exacerbated by the proximity of roads, the removal and fragmentation of the original rainforest, and altered flow regimes caused by the extant water withdrawal structures. The reduction of the Carioca aquatic biota can also be interpreted as an effect of diffuse pollution sources inherent to the scale and form of urban development that took place in the Carioca watershed plains, especially in terms of channel structure and hydrological conditions.

In different ways and to varying degrees, there is a growing awareness of these circumstances and of the need to put urban sustainability into practice. While there have been several governmental and community-based efforts to address these interrelated problems, the complexity of the challenge remains daunting. Yet significant progress has been made by the local community in building citizens' awareness of historic, cultural and environmental values, as well as by the Rio city government in creating legal instruments to protect the local cultural and natural heritage. Nevertheless, current policies and funding mechanisms still do not provide effective protection for local freshwater ecosystems and Rio's rainforest. Institutional solutions for polluted streams or rivers still rely mainly 
on outdated techniques: diversions, channelization, and piping underground. Still, recent initiatives have included water quality monitoring efforts and remediation attempts, albeit restricted to the mouths of the rivers that discharge into Guanabara Bay.

As argued by Ehrlich [7], carrying capacity, although a fundamental concept for characterizing the dynamics of landscape resilience to change, is still very difficult to measure. The assemblage of several layers of information presented in this study called for the use of NUSVAP to gauge Rio's urban streams and riparian slope-carrying and adaptive capacities. The application of a new visual assessment protocol to neotropical urban settings (NUSVAP) proved to be a useful, efficient and flexible tool in gauging the effects of landscape change along urban streams in and around Rio, helping to facilitate the process of engaged inquiry, while demonstrating the utility of this approach to inhabitants of the Carioca watershed.

Further validation and additional tests in different settings — including the use of different reference rivers - are recommended to verify NUSVAP's adequacy as an initial assessment of actual levels of ecological health and integrity of local urban streams. As a first-cut approach, meant to be applied by trained lay persons, NUSVAP may be useful as an orientation to enhance community-based awareness of watershed resilience limits as well as to inform stream recovery actions, combined with higher-level assessment technologies, such as water chemistry and macro-invertebrates surveys.

This study's cross-scale reading of the urban mountainous landscape of Rio de Janeiro, grounded by landscape ecology and urban morphology theory, generated clues to understanding the structure, formation and transformation processes of Rio de Janeiro's hillsides, and revealed implications of the cultural forces and conflicts in its varied communities. The logic of regulation of the mountainous urban space implemented in Rio de Janeiro followed the principle of spatial segregation, derived from the social and economic structure of Brazilian society. Controversially, Rio's society, in particular, acquiesced to live with its antithesis, represented by the permanence of slum areas on the valued areas of the city. The very existence of favelas, and their relationships of complementarity and interdependence with the formal fabric of the city, are part of this logic.

The detailed analyses conducted on the upper Carioca watershed were corroborated through correlation with the two reference sites in the city of Rio de Janeiro and four reference Brazilian cities to identify patterns and clarify processes of landscape formation and transformation. The findings refute certain dogmas concerning urban settlements on the hillsides of Rio Janeiro and other Brazilian cities, and reveal questionable treatment of these issues by the city government. The process of landscape change and management describes interwoven evolutionary cycles and relationships that have conditioned-and continue to influence-current local environmental conditions and landscape sustainability.

The following are some key factors that help to explain the process of landscape change on the urban and urbanizing slopes of Rio de Janeiro, and may inform potential restorative efforts:

1. Landscape structure and function: Characteristic features of the occupation of hillsides in Rio de Janeiro include the spread of occupation from the valley bottoms and the main lines of natural drainage, which act as vectors to induce urban occupation and tend to concentrate processes of consolidation and vertical growth of occupation. 
2. Pattern-processes relationship: The Carioca watershed's formal and informal settlements have a relationship of contiguity, connected by the river, the winding roads and the local labor market dynamics that link them. The strategy designed by the government to minimize the conflicts generated by social polarization that characterizes the occupation of the slopes of the city of Rio de Janeiro lies in the release of legal limits and constraints set out in legislation.

3. Land ownership and illegality: Most of the area occupied by the studied favelas was originally privately owned. The emergence of the first nuclei of formal and informal settlements was simultaneous and spawned interdependent relationships. The first urban settlements on the hillsides had their origin in the decline of agriculture and the opening of roads and streets on the slopes. The first favelas nuclei were spurred by early landowners, the Catholic Church, and other institutions, both public and private. Currently, most of the urban land located on Rio de Janeiro's slopes is in the hands of a few owners, essentially constituting large estates. The deeds of some of these tracts are not even registered at the City Hall.

Regarding the aspect of legal property, the slums, as demonstrated by this study, are not entirely illegal. Part of the settlements is privately held land or blends certain formal characteristics: pieces were collectively acquired from former landowners, had lots individually legalized over time, or remain in use by permission of certain institutions. The spatial configuration, however, is irregular in that it does not follow city zoning and building codes and urban development standards. In fact, only recently has the city defined regulations for these areas. In their turn, upper income neighborhoods also did not fully comply with current legislation. Conflicts between private property boundaries and public land, horizontal and vertical building additions, excessive impermeability of land cover, and rampant vegetation removal also occur in formal neighborhoods.

Throughout the upper Carioca watershed, private properties overlap each other and stake informal claims on adjacent forested areas protected by the Federal government or supervised by the Municipal government, forming an interwoven patchwork with conflicting ownership and management claims. Rio's social model and resulting spatial configurations on the slopes of the Tijuca Massif were based on the long-held belief that real estate forces favoring middle and upper classes would have the power to remove and replace the slums. This study's findings suggest a different reality.

4. Open spaces: The open spaces on the slopes serve multiple functions. They act as vegetated corridors that penetrate and cross the occupied areas, providing ecological connection to the rainforest and helping to maintain a degree of carrying and adaptive capacity in mountainous areas. These spaces include the forest reserves, the connected back bounds of residential plots, the forested open spaces located along the edges of the slums, the small social spaces nested deep within each neighborhood, and the open spaces located along the valley bottoms-all forms of open spaces in the upper Carioca - deserve special attention, care and protection due to their multifunctional nature. Yet the neglect, privatization, and incremental replacement of open spaces with built form continue to occur in both formal and informal settlements.

5. Regulation: Parameters set by city legislation so far (whether for high or low income strata settlements) are insufficient to match the complex geomorphology of the mountainous areas of the city. Grounded in previous works [65-70], we argued the need to associate altimetry, slope (already applied in other Brazilian cities urban planning legislation), shape of slope, and the 
configuration, distribution and management of open spaces and native vegetation as additional parameters for sustainable landscape planning. As demonstrated by previous local surveys [66-69], it is not just the steeper areas that are particularly susceptible to landslides. Thus, it is imperative to establish the watershed as an urban planning unit for the purpose of formulating an integrated zoning that would restrict cut and fill on $15^{\circ}$ (approximately 25\%) and greater slopes, and prohibit new occupations in between $15^{\circ}$ and $20^{\circ}$ slopes in concave/convergent areas and above $35^{\circ}$ in convex/divergent areas (see Figure 11).

A recurring device during early land parceling was the allocation of areas for forest reserves without records of public ownership. Later, these lands would essentially serve as a stock of privately owned land waiting to be exploited for profit or otherwise restricted for private enjoyment. However, when these areas were invaded by favelas, their "owners" rush to relinquish their ostensible holdings (and associated occupants) to the government. The diverse and plural character of the slums, in terms of their interior landscape morphology, socio-spatial dynamics, socioeconomic stratification, typologies and construction standards, land situation and land use have not yet been assimilated into public policy. Additionally, the decontextualized perspective of city planners, disregarding the diversity of relations between the slums and formal neighborhoods around them, undermine the potential for public policy to promote sustainability and inclusivity in Rio's mountainous environs.

Figure 11. Shape of slope [3].

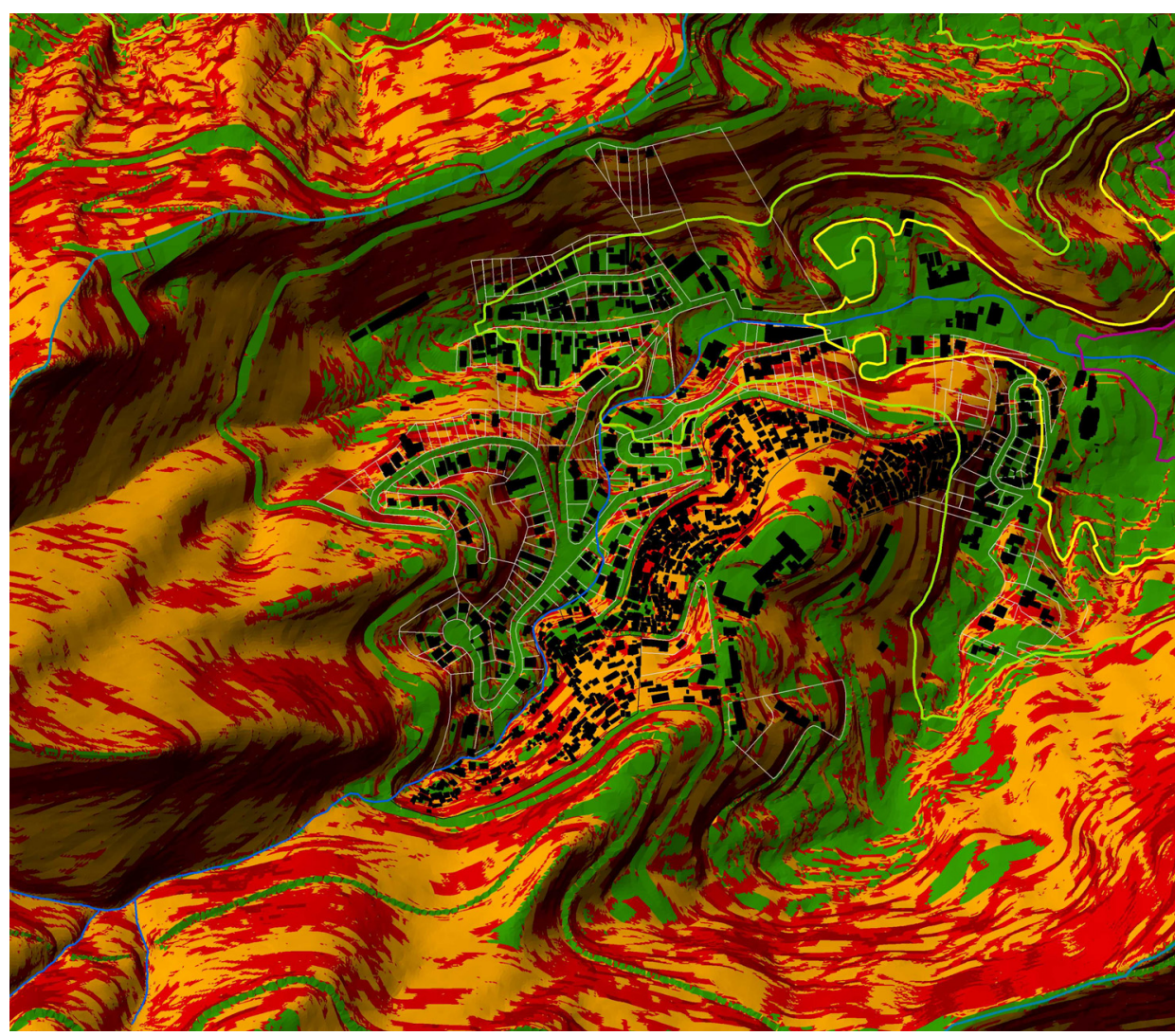

0-15 degrees $15-20$ degrees 20-25 degrees $25-35$ degrees $35-45$ degrees $>45$ degrees

The analytical methods developed in both research phases contributed to an understanding of the processes that produced and shaped the mountainous landscape of Rio de Janeiro over time. 
The consideration of those processes is fundamental to the formulation of strategies and instruments for the effective protection and sustainability of Carioca's slopes, riparian corridors and waters. Processes of landscape and land use transformation, insufficient policy and regulation controlling urban occupation, and fragmented and chaotic spatial patterns have conspired to generate the socio-environmental conflicts and socio-spatial segregation framework that characterize the slopes of Rio de Janeiro today.

The formal and informal forms of occupation on the slopes are complementary, functioning as an extension of one another. When considered through the lenses of structuring processes; density, architectural types, educational level, relationship with open spaces, and real estate markets, its fluid boundaries become apparent. Both forms of occupation have similarities in terms of the relations between public and the private space. In both cases, there is a well marked separation between the public or collective spaces (undervalued and neglected) and the private domain (emphasized, fetishized and prioritized), demarcated with walls, fences and railings in the formal neighborhoods and expressed in the slums by the super expansion of the private domain over the public domain. The lack of definition between public and private domains and the looming insecurity of life in the slums compelled the need to assert private holdings over common areas.

As Soares [71] pointed out, environmental protection policies and programs acquire political overtones when they conveniently serve the interests of privileged real estate and the labor market. The use of environmental reasons to justify attempts of territorial control is not new; in Rio it dates from the 18th century, supported by the hygienist discourse [72,73]. But recently, the clash between environmental and social rationales has strained both federal and municipal jurisdictions, as well as Brazilian society at large. In print media, prevailing voices still defend the legitimacy of the occupancy of the slopes by the highest social strata of the population, arguing that this type of occupation is more "sustainable" and has the power to restrain informal occupation. As has been demonstrated by this study, this is not the case.

The assessment of landscape morphology and processes of landscape transformation of the hillsides of Rio de Janeiro indicated that open spaces contribute strongly to the resilience of the rainforest on the slopes of the city. The research also indicates an imperative of ensuring open space heterogeneity, multifunctionality, flexibility, adaptability and connectivity to provide support and sustainability to Rio de Janeiro's forests and its urban inhabitants, and to foster the capacity of regeneration of its urban systems. Given this context, it is vital that transitionary buffer zones between urban spaces and the natural and cultural heritage be protected and extended. Concurrently, land use and occupation patterns must be organized to promote a gradation between urban and protected areas, with integration of urban, environmental, social, economic and cultural factors. It is also critical to address institutional impediments, such as a lack of broad and inclusive well-defined property rights.

Our Common Journey: A Transition toward Sustainability [74] and follow-up Earth Summit reports progressively stressed that sustainability requires reconciling environmental, social equity and economic demands, widening the focus of Our Common Future [4]. Based on longitudinal, multi-dimensional research, we would assert that eco-hydrological protection and buffering, and promoting participatory principles of flexibility, multifunctionality, and economic and social equity are key to enhancing the capacity for recovery as well as to achieving sustainability in the city of Rio de Janeiro. 
This research helps to coalesce a restorative riparian urbanism perspective that seeks to interweave urban and hydroecological functions and patterns within sustainable cityscapes and bioregions. It recognizes and protects riparian ecosystem services, and calls for ample space for riparian and aquatic processes and organisms strongly connected to larger biophysical systems. At the same time, it sees urban riparia through a progressive urbanist lens. It celebrates the city-water interface as an ordering network, an essential counterpoint to built form, and an accessible source of sustenance, conviviality, inclusivity, and inspiration for all life in the city.

\section{Conclusions}

This article has outlined complementary methods of gauging the process of landscape change in Rio's Carioca River valley and evaluating the degree of degradation of an urban watershed resulting from human-induced impacts and stressors on the stream's upper ecosystem. The combination of biophysical and water quality characterizations and in-depth socio-cultural inquiries provided insights as to how the Carioca River corridor has changed in response to dominant landscape transformations that occurred in Rio through time. This work also provided an integrated picture of numerous factors leading up to, and currently influencing, resilience and regenerative capacity of an urban landscape system.

The foregoing methodological approach and these conclusions compile, align and empiricize some of the emerging theories in sustainability and resilience as they apply to the city. Increased resilience (and, by extension, sustainability) is based on and informed by an understanding of environmental, ecological, social, and economic dynamics through time and space [27-30,35]. An important aspect of resilience analysis is an understanding of landscape systems conditions and performance [5,8,27,36]. Hence, there is a need to integrate knowledge across a range of linked transdisciplinary approaches. This research offers insights on select nature-society interactions and socio-ecological systems aspects of a tropical urban watershed landscape.

The main contribution of the present research stems from the application of watershed-based methodologies to investigate interactions among cultural and ecological landscape components, using landscape ecological, landscape morphology, biological and urbanistic parameters to assess the roles of landscape change on the urban environmental quality of a neotropical setting, ranging from watershed to urban lot and micro-ecosystems scales.

In brief, this research suggests that watershed-based urban landscape studies would benefit from including these basic principles:

- investigating the landscape through complementary scales of time and space;

- understanding the influence of cultural perceptions of nature on landscape management;

- identifying the connections and dissociations between ecological and cultural dimensions;

- incorporating the visions and roles of different agents of landscape transformation;

- acknowledging the role of open spaces in structuring buffering capacity, restoring resilience and building on landscape sustainability.

Beyond Rio, the multi-faceted approach applied in this study may be transferable, with some adjustments, to other tropical settings. Published processes of inquiry into urban tropical environments 
are still relatively few in number, as are methodologies that carefully integrate selected techniques from ecological science, humanities and landscape studies. Therefore, this methodological framework may serve as a precedent in the development of new, proactive approaches to sustainable landscape planning and design in environmentally-stressed urban tropical contexts.

This paper argues that one important step towards encompassing urban sustainability in developing countries is focusing on water and vegetation cover as key elements of urban landscape planning. We stress that the integrated methods applied and developed in this research coalesce into a robust methodology for sustainable landscape planning that may be employed to help gauge and restore resilience. It may also serve to inform community volunteers, planners and civic decision-makers as they promote regenerative actions that reverse disturbance events and encourage transformations leading to robust and equitable sustainability. In the Carioca River watershed, changes in land use and land cover and non-adequate land regulation and management decisions combine to impact social-ecological systems in different ways, leading to a loss of landscape functionality and increasing vulnerability. As a result, landscape adaptive capacity and resilience are affected. It is this generation's responsibility to reverse these trends.

\section{Acknowledgments}

Fieldwork in Brazil undertaken by the first author was funded by The Graduate School of Pennsylvania State University and the Alma Heinz and August Pohland Graduate Scholarship. We acknowledge the support of the Rio de Janeiro City Government, the Instituto Municipal de Urbanismo Pereira Passos, the Secretaria Municipal de Urbanismo, the Sub-Secretaria Municipal de Patrimonio Cultural. We appreciate individual assistance from Antonio Bernardo de Carvalho, Joan Schumacher, Lysle Sherwin, Ana Luiza Coelho Netto, Darcílio Baptista, Daniel Nadenicek, Deryck Holdsworth, Bill Elmendorf, Jonathas Magalhães Pereira da Silva, Maria Paula Albernaz, Luiz Otávio Pedreira, Timothy Moulton, Rogério Ribeiro de Oliveira, Mariana Egler, Mariana Silveira, Sandra Magalhães, Rodolfo Paranhos, João Crisóstomo Oswaldo Cruz, Bruno Henriques Coutinho, Raphael Urbano de Andrade, Marco Zambelli, Murilo Santos de Medeiros, Gustavo Peres Lopes, Alice Amaral dos Reis, Claudia Muricy, Daniel Mancebo, Antonio Barboza Correia, Carla Cabral and Paula Serrano. Finally, we thank the Instituto Municipal de Urbanismo Pereira Passos and the Secretaria Municipal de Urbanismo of Rio de Janeiro for access to cadastral bases, orthophotos and allotment bases and the two anonymous reviewers for their valuable comments on the manuscript.

\section{Conflict of Interest}

The authors declare no conflict of interest. 


\section{References}

1. Gould, S.J. Bully for Brontosaurus: Reflections in Natural History; W.W. Norton \& Company: New York, NY, USA, 1991.

2. Schlee, M.B. Landscape Change Along the Carioca River, Rio de Janeiro, Brazil; Master's Thesis, The Pennsylvania State University: University Park, PA, USA, 2002.

3. Schlee, M.B. A Ocupação das Encostas do Rio de Janeiro: Morfologia, Legislação e Processos Sócio-Ambientais. Ph.D. Dissertation, Federal University of Rio de Janeiro, Rio de Janeiro, Brazil, 2011.

4. Brundtland, G.H.; Khalid, M. Our Common Future; Report of the World Commission on Environment and Development, United Nations Document A/42/427; Oxford University Press: Oxford, UK, 1987.

5. Arrow, K.; Bolin, B.; Costanza, R.; Dasgupta, P.; Folke, C.; Holling, C.S.; Jansson, B.-O.; Levin, S.; Mdler, K.-G.; Perrings, C.; Pimentel, D. Economic growth, carrying capacity, and the environment. Science 1995, 268, 520-521.

6. Acselrad, H. Sustainability and Territory: Meaningful Practices and Material Transformations. In Sustainability and the Social Sciences: A Cross-Disciplinary Approach to Integrating Environmental Considerations into Theoretical Reorientation; Becker, E., Jahn, T., Eds.; ZED Books: London, UK, 1999; pp. 37-57.

7. Ehrlich, P.; Kareiva, P.M.; Daily, G.C. Securing natural capital and expanding equity to rescale civilization. Nature 2012, 486, 68-73.

8. Folke, C. Resilience: The emergence of a perspective for social-ecological systems analyses. Glob. Environ. Change 2006, 16, 253-267.

9. Holdren, J.P. Science and technology for sustainable well-being. Science 2008, 319, 424-434.

10. Leitao, A.B.; Ahern, J. Applying landscape ecological concepts and metrics in sustainable landscape planning. Landsc. Urban Plan. 2002, 59, 65-73.

11. Johnson, B.R.; Hill, K. Introduction: Toward Landscape Realism. In Ecology and Design: Frameworks for Learning; Johnson, B.R., Hill, K., Eds.; Island Press: Washington, DC, USA, 2002; pp. 1-28.

12. McHarg, I.L. Design with Nature; The Natural History Press: New York, NY, USA, 1969.

13. Forman, R.T.; Godron, M. Landscape Ecology; John Wiley \& Sons: New York, NY, USA, 1986.

14. Forman, R.T. Land Mosaics: The Ecology of Landscapes and Regions; Cambridge University Press: Cambridge, MA, USA. 1995.

15. Turner, M. Landscape ecology: The effect of pattern on processes. Annu. Rev. Ecol. Syst. 1989, 20, 171-191.

16. Turner, M.G., Gardner, R.H., Eds. Quantitative Methods in Landscape Ecology; Springer-Verlag: New York, NY, USA, 1991.

17. Zonneveld, I.S. Land Ecology: An Introduction to Landscape Ecology as a Base for Land Evaluation, Land Management and Conservation; SPB Publishing: Amsterdam, The Netherlands, 1995.

18. Environmental Protection Agency. Watershed Approach Framework; Environmental Protection Agency, Office of Water: Washington, DC, USA, 1996. 
19. Environmental Protection Agency. Volunteer Stream Monitoring: A Methods Manual; Document EPA \#841-B-97-003, Environmental Protection Agency, Office of Water: Washington, DC, USA, 1997.

20. Environmental Protection Agency. Urbanization and Streams: Studies of Hydrologic Impacts. Non-point Source Pollution Control Program; Environmental Protection Agency, Office of Water: Washington, DC, USA, 1998.

21. Environmental Protection Agency. Rapid Bioassessment Protocols for Use in Streams and Wadeable Rivers: Periphyton, Benthic Macroinvertebrates, and Fish, 2nd ed.; Environmental Protection Agency, Office of Water: Washington, DC, USA, 2000.

22. Ndubisi, F. Ecological Planning: A Historical and Comparative Synthesis; Johns Hopkins University Press: Baltimore, MD, USA, 2002.

23. Hough, M. Cities and Natural Process: A Basis for Sustainability; Routledge: New York, NY, USA, 1995.

24. Nassauer, J.I. Placing Nature: Culture and Landscape Ecology; Island Press: Washington, DC, USA, 1998.

25. Ahern, J. Spatial Concepts, Planning, Strategies and Future Scenarios: A Framework Method for Integrating Landscape Ecology and Landscape Planning. In Landscape Ecological Analysis: Issues and Applications; Klopatek, J., Gardner, R., Eds.; Springer: New York, NY, USA, 1999; pp. 175-201.

26. Moudon, A.V.; Hubner, M. Monitoring Land Supply with Geographic Information Systems Theory, Practice, and Parcel-Based Approaches; Wiley, John \& Sons: New York, NY, USA, 2000.

27. Holling, C.S. Understanding the complexity of economic, ecological, and social systems. Ecosystems 2001, 4, 390-405.

28. Turner, M.G.; Gardner, R.H.; ONeill, R.V. Landscape Ecology in Theory and Practice; Springer-Verlag: New York, NY, USA, 2001.

29. Ahern, J. Planning and Design for Sustainable and Resilient Cities: Theories, Strategies and Best Practices for Green Infrastructure. In Water-Centric Sustainable Communities; Novotny, V., Ahern, J., Brown, P., Eds.; John Wiley and Sons: Hoboken, NJ, USA, 2010; pp. 135-176.

30. Ahern, J. From fail-safe to safe-to-fail: Sustainability and resilience in the new urban world. Landsc. Urban Plan. 2011, 100, 341-343.

31. Odum, E.; Brewer, R.; Barrett, G. Fundamentals of Ecology, 5th ed.; Cengage Learning: Stamford, CT, USA, 2004.

32. Kostof, S. The City Shaped: Urban Patterns and Meanings through History; Thames \& Hudson: London, UK. 1991.

33. Lamas, J.M. Morfologia Urbana e o Desenho da Cidade; Fundação Calouste Gulbekian: Lisboa, Portugal, 1992.

34. Panerai, P.; Depaule, J.; Demorgon, M. Analyse Urbaine; Editions Parenthèses: Marseille, France, 1999.

35. Weins, J. Toward an Unified Landscape Ecology. In Issues and Perspectives in Landscape Ecology; Weins, J., Moss, M., Eds.; Cambridge University Press: Cambridge, MA, USA, 2005. 
36. Wang, S.-H.; Huang, S.-L.; Budd, W. Resilience analysis of the interaction of between typhoons and land use change. Landsc. Urban Plan. 2012, 106, 303-315.

37. United States Department of Agriculture. Stream Visual Assessment Protocol; Technical Note 99-1; National Water and Climate Center, Natural Resources Conservation Service: Washington, DC, USA, 1998.

38. Petersen, R.C. RCE: A riparian, channel, and environmental inventory for streams in the agricultural landscape. Freshw. Biol. 1992, 27, 295-306.

39. GEOHECO-UFRJ/SMAC-PCRJ. Estudos de Qualidade Ambiental do Geoecossistema do Maciço da Tijuca: Subsídios à Regulamentação da APARU do Alto da Boa Vista; PCRJ/SMAC: Rio de Janeiro, Brazil, 2000.

40. Brazil, Instituto Brasileiro de Geografia e Estatistica, Census 1991, 2000 and 2010. Available online: http://www.ibge.gov.br/home/download/estatistica.shtm (accessed on 20 May 2011).

41. Rio de Janeiro, Instituto Municipal de Urbanismo Pereira Passos, Armazem de Dados, Estatisticas Municipais, Caracteristicas Gerais, tables 2972, 2917 and 1754. Available online: http://www.armazemdedados.rio.rj.gov.br/ (accessed on 6 October 2010).

42. Riley, A.L. Restoring Streams in Cities: A Guide for Planners, Policymakers and Citizens; Island Press: Washington, DC, USA, 1998.

43. Rosgen, D. Applied Stream Morphology; Wildland Hydrology: Pagosa Springs, CA, USA, 1996.

44. Newbury, R.W.; Gaboury, M.N. Stream Analysis and Fish Habitat Design: A Field Manual; Newbury Hydraulics Ltd.: Gibsons, BC, Canada, 1993.

45. Leopold, L.B.; Wolman, M.G.; Miller, J.P. Fluvial Processes in Geomorphology; W.H. Freeman and Company: San Francisco, CA, USA, 1964.

46. Coelho Netto, A.L. A Geoecologia e a Arquitetura da Paisagem do Rio de Janeiro no Século XXI: Da Degradação à Reabilitação Funcional da Cidade e da Floresta Atlântica Remanescente. In Águas Urbanas: A Regeneração Ambiental como Campo Disciplinar Integrado; Tangari, V., Schlee, M.B., Andrade, R., Dias, M.A., Eds.; PROARQ-FAU/UFRJ, ETU/UFRJ, ABAP-RIO, IPP/PCRJ: Rio de Janeiro, Brazil, 2007.

47. Coelho Netto, A.L. Ecossistemas de Encostas. Protocolo do Rio/Estudos e Pesquisas-Seminário Rio: Próximos 100 anos, 2007. Available online: http://www.rio.rj.gov.br/ipp/ (accessed on 20 May 2011).

48. Coelho Netto, A.L. Catastrophic Landscape Evolution in a Humid Region (SE Brasil): Inheritances from Tectonic, Climatic and Land Use Induced Changes. In Supl. Geogr. Fis. Dinam. Quat. Vol. III; Fourth International Conference on Geomorphology: Bologna, Italy, 1999; pp. 21-48.

49. Coelho Netto, A.L. Surface Hydrology and Soil Erosion in a Tropical Mountainous Rainforest Drainage Basin, Rio de Janeiro; Ph.D. Dissertation, Katholieke Universiteit Leuven: Leuven, Belgium, 1985.

50. Observatório das Metrópoles/IPPUR/FASE. Análise das regiões Metropolitanas do Brasil. Como Andam as metro Poles Brasileiras. Available online: http://www.observatoriodasmetropoles .ufrj.br/como_anda/ (accessed on 7 August 2010).

51. Brazil, Instituto Brasileiro de Geografia e Estatistica. Available online: http://www.ibge.gov.br/ cidadesat/topwindow.htm?1/ (accessed on 20 May 2011). 
52. Coutinho, B.H. Domínios Geo-Hidroecológicos e Padrões de Fragmentação da Mata Atlântica-Bacia do Macacu. Ph.D. Dissertation, Geosciences Institute/UFRJ, Rio de Janeiro, Brazil, 2001.

53. Schlee, M.B.; Coelho Netto, A.L.; Tamminga, K. Mapeamento Ambiental e Paisagístico de Bacias Hidrográficas Urbanas: Estudo de Caso do Rio Carioca. In: Rios e Paisagem Urbana em Cidades Brasileiras; Costa, L., Ed.; Viana \& Mosley: Rio de Janeiro, Brazil, 2006; pp. 33-55.

54. Cavalcanti, N. Rio de Janeiro, Centro Histórico 1808-1998. Marcos da Colônia; Dresdner Bank: Rio de Janeiro, Brasil, 1998.

55. Rezende, R. Memórias e Curiosidades do Bairro de Laranjeiras; João Fortes Engenharia: Rio de Janeiro, Brazil, 1999.

56. Abreu, M.A. Cidade Brasileira: 1870-1930. In Urbanização e Cidades: Perspectivas Geográficas; Sposito, M.E.B., UNESP/GASPPERR: Presidente Prudente, Brazil, 2001.

57. Bohadana, E.B. Guararapes: Uma História de Encontros e Desencontros. Master's Thesis, Programa de Pós-Graduação em Engenharia/COPPE/UFRJ, Rio de Janeiro, Brazil, 1983.

58. Dantas, A.C.; Senra, K. Diagnóstico das Comunidades Guararapes, Vila Cândido e Cerro-Corá; Teixeira de Freitas/Programa Favela-Bairro PCRJ/SMH: Rio de Janeiro, Brazil, 1994.

59. Silva, J.M.; Tangari, V.R. Ensinar Cegos a "Ver": A Crise Urbana Do Brasil. In Anais do XVII Congresso Brasileiro de Arquitetos; IAB/RJ: Rio de Janeiro, Brazil, 2003.

60. Santos, C.N.F. O que Transforma e o que É Transformado. In Desenho Urbano; Turkienicz, B., Ed.; Cadernos Brasileiros de Arquitetura, Projeto Editores Associados: São Paulo, Brazil, 1984.

61. Cardoso, A.L. O Programa Favela-Bairro-Uma Avaliacao. In Anais do Seminario de Avaliacao de Projetos IPT Habitacao e Meio Ambiente Assentamentos Urbanos Precarios; Paginas e Letras Editora e Grafica LTDA: Sao Paulo, Brazil, 2002; pp. 37-50.

62. Andrade, L.S. Espaços Publicos e Favelas: Uma Analise da Dimensão Publica dos Espaços Coletivos Não-Edificados da Rocinha. Ph.D. Dissertation, PROURB/FAU/UFRJ: Rio de Janeiro, Brazil, 2002.

63. Farias, J.S. A Forma da Informalidade: Uma Análise da Morfologia Urbana da Rocinha. Ph.D. Dissertation, PROURB/FAU/UFRJ, Rio de Janeiro, Brazil, 2009.

64. Coelho, G.N. Brincadeiras Infantis nos Espaços Livres da Rocinha. Master's Thesis, PROARQ/FAU/UFRJ, Rio de Janeiro, Brazil, 2004.

65. Ruhe, R.V. Geomorphology: Geomorphic Processes and Surficial Geology; Houghton Mifflin Company: Boston, MA, USA, 1975.

66. Avelar, A.S. Iniciação e Desenvolvimento de Fluxos Detríticos em Encosta: Ensaios Triaxiais de Choque e em Caixa Experimental Abordando o Caso do Soberbo. Ph.D. Dissertation, COPPE/UFRJ, Rio de Janeiro, Brazil, 2003.

67. Avelar, A.S. Investigação Histórica e Geotécnica do Movimento de Massa do Soberbo. Master's Thesis, COPPE-UFRJ, Rio de Janeiro, Brazil, 1996.

68. Avelar, A.S.; Lacerda, W.A. Causas iniciais do movimento de massa da encosta do Soberbo, Rio de Janeiro, Brasil. In 2 a Conferência Brasileira sobre Estabilidade de Encostas; ABMS, ABGE, ISSMGE: Rio de Janeiro, Brazil, 1997; pp. 3-12. 
69. Coelho Netto, A.L.; Avelar, A.; Fernandes, M.; Lacerda, W. Landslide susceptibility in a mountainous geoecosystem, Tijuca Massif, Rio de Janeiro: The role of morphometric subdivision of the terrain. Geomorphology 2007, 7, 120-131.

70. Valeriano, M. Topodata: Guia de Utilização de Dados Geomorfológicos Locais; INPE: São José dos Campos, Brazil, 2008.

71. Soares, M.L.G. Floresta Carioca: An Interface Urbano-Florestal do Parque Nacional da Tijuca. Ph.D. Dissertation, IPPUR/UFRJ, Rio de Janeiro, Brazil, 2006.

72. Abreu, M.A. Reconstruindo uma história esquecida: Origem e expansão inicial das favelas do Rio de Janeiro. Espaço e Debates 1994, 14, 34-46.

73. Pechman, R. O Urbano Fora do Lugar? Transferências e Traduções das Idéias Urbanísticas nos Anos 20. In Cidade, Povo e Nação. Gênese do Urbanismo Moderno; Ribeiro, L.C.Q., Pechman, R., Eds.; Civilização Brasileira: Rio de Janeiro, Brasil, 1996.

74. National Research Council Board on Sustainable Development. Our Common Journey: A Transition toward Sustainability; National Academy Press: Washington, DC, USA, 1999.

(C) 2012 by the authors; licensee MDPI, Basel, Switzerland. This article is an open access article distributed under the terms and conditions of the Creative Commons Attribution license (http://creativecommons.org/licenses/by/3.0/). 